The International Journal of Banking and Finance, Volume 10 (Number 1), 2013: Pages 1-33

\title{
MARKET CONDITIONS AND FUND FLOWS: EVIDENCE FROM HEDGE FUNDS
}

Wen-Hsiu Chou (Florida International University, USA), Dongmin Ke (Kean University, USA) Danielle Xu (Gonzaga University, USA/Hanken School of Economics, Finland)

\begin{abstract}
This paper investigates whether market conditions affect fund investor behavior in the hedge fund industry, especially the volatility in the up and down markets. Using a sample of 5,254 individual hedge funds from January 1994 to December 2009, we find that hedge fund investors tend to invest less during upand down-volatile markets. They also adopt different investment strategies in these two market conditions. When market is calm and relatively predictable, there is almost no difference in their behaviors between up and down markets. We also find that smart money effect exists over both 3- and 12-month periods under all market conditions except volatile markets. A further investigation suggests that the observed smart money effect is largely driven by hedge fund performance persistence, which is present and significant in quiet markets only. The findings are relevant to portfolio theories concerning investor recognition of upside and downside volatilities.
\end{abstract}

Keywords: Hedge funds, Flow sensitivities, Smart money effect, Performance persistence, Time-varying performance, Downside/upside volatility

JEL Classification: G11, G23

\section{Introduction}

How investors allocate their assets to form portfolio according to risk, especially the risk in the up and down markets, is one of the topics under debate. On the one hand, practitioners use Roy's (1952) safety first principle to argue that investors only care about downside volatility. On the other hand, academic researchers claim that the risk is important in both up and down markets. ${ }^{1}$ Although Ang, Chen, and Xing (2006) have provided evidence to show that investors require a higher return to hold stocks with high downside beta than stocks with low downside beta, it is still not clear whether investors are only concerned about the downside volatility. It is possible that upside volatility also influences investors' decision making. In this study, we separate market conditions into up, down, quiet, and volatile markets, and their combinations to investigate how market conditions affect fund investor behavior in the hedge

\footnotetext{
${ }^{1}$ See Rom and Ferguson (1993,1994), Kaplan and Siegel (1994a,b), and Nawrocki (1999).
} 
fund industry. ${ }^{2}$ If upside volatility has no effect on investment behaviors, investors will have the same investment strategies across all market conditions except the down-volatile market; otherwise, investors may show different behaviors between volatile and quiet markets, and probably between up-volatile and down-volatile markets. We also examine whether market conditions have an impact on investors' ability to identify outperforming hedge funds and hedge funds' performance persistence. The findings are relevant to portfolio theories concerning investor recognition of upside and downside volatilities.

Studying the relation between hedge fund flows and market conditions allows for better understanding about investor's behavior and attitude toward risk at the market level. During the 2008 financial crisis, most hedge fund investors fled out of the industry regardless of the fund performance. ${ }^{3}$ This seems to support Roy's principle that investors care about downside volatility and prefer safety first. As Kelly (1997) documents, investors' wealth is positively correlated with the probability of being smart money and negatively associated with the probability of being a noise trader. Hedge fund investors are generally considered the most sophisticated investors on the market and possibly better informed, partly due to the unique characteristics of hedge fund investors. ${ }^{4}$ In addition, they are likely equipped with sound financial knowledge. Thus, it is reasonable to assume that hedge fund investors are not noise traders. If fund investors have certain preferences over market risk, their investment decisions will vary with market volatility. Docking and Koch (2005) show that market direction and volatility affect how investors respond to dividend change announcements. Avramova et al. (2011) suggest that hedge fund investors will benefit by incorporating predictability which is based on macroeconomic variables into their investment decisions. Among all macroeconomic variables, market volatility is of particular importance.

Hedge fund performance under each market condition also provides some insights into the debate. As one of the most sophisticated investment advisors, hedge fund managers possess the freedom of adopting flexible investment strategies. As a result, they can adjust fund betas more easily than their mutual fund peers, especially during volatile markets, thus producing better risk-adjusted returns for fund investors. However, hedge fund managers are unable to deal with volatility to provide reliable risk-adjusted returns. ${ }^{5}$ Some studies have documented that hedge fund performance is time varying and seems to

\footnotetext{
${ }^{2}$ We refer a market characterized by both down and volatile as down-volatile market, both down and quiet as downquiet market, both up and volatile as up-volatile market and both up and quiet as up-quiet market, respectively.

${ }^{3}$ For example, an article from New York Times shows 'The gilded age of hedge funds is losing its luster. $\cdots$ lose $\$ 180$ billion during the last three months. Investors, particularly wealthy individuals, are heading for the exits.' (New York Times, October 22, 2008)

${ }^{4}$ By laws, hedge fund investors must be accredited investors who own a minimum net wealth of $\$ 1,000,000$ or have a minimum consistent income of $\$ 200,000$ in the past and future years.

${ }^{5}$ For example, an article from the Economist complains that 'We (hedge fund managers) use to promise "absolute returns" but this pledge has proved impossible to honor. Instead, we're going to give you "risk-adjusted" returns or, failing that, "relative" returns. - . It is also time to move on from the concept of delivering "alpha",
} 
depend on general business cycles and market movements (for example, see Fung and Hsieh, 1999; Edwards and Caglayan, 2001; Ennis and Sebastian, 2003; and Capocci, Corhay, and Hübner, 2005). When evaluating managerial skills, Chen and Liang (2007) find that self-reported market timing hedge funds generally possess timing abilities, but patterns of market timing behavior are significantly different in various market states. Therefore, market conditions should play a role in the relation between hedge funds and fund investors, and fund investor behavior.

Using a comprehensive hedge fund sample from the January 1994 to December 2009 period that sees a number of significant equity market swings, we start our analysis by examining fund performance and fund flows independently under different market conditions. Our primary investigation on hedge fund performance alone indicates that hedge funds only slightly outperform in up markets than in down markets, but generate much better returns in quiet markets than in volatile markets. When fund performance is examined with further breakdown of different market conditions, we find that hedge funds generate the worst risk-adjusted returns in down-volatile markets. Hedge funds do not perform well in upvolatile markets either. This indicates that hedge funds may offer some 'hedge' protections in down markets to some extent, but they cannot offer the same protections in volatile markets. On the other hand, while there is very little difference in fund flows during up and down markets, hedge funds experience much higher flows in quiet markets than volatile markets. A further investigation with breakdown of market conditions suggests that hedge fund investors tend to invest much more during down-quiet markets while refrain much of their money during up-volatile and down-volatile markets. Our results are consistent with previous findings in mutual fund industry that risk-averse fund investors reduce their investment when markets are expected to be more volatile (e.g., see Luo, 2003; Ederington and Golubeva, 2009; Ferson and Kim, 2012) and in the general finance that investors request higher returns for bearing macroeconomic risk (Savor and Wilson, 2012). With initial findings that suggest an asymmetric impact of a particular market condition on both fund performance and new flows, we then turn to a more formal examination on the flow-performance relation under different market conditions while controlling for multiple non-performance related fund characteristics.

Next, we explore in greater detail flow sensitivities to fund past performance in various market states by using a piecewise linear regression model similar to the existing literature. Compared to the mutual fund industry, behavior of hedge fund flows is usually more complicated and affected by many unique features of the hedge fund industry such as high minimum investments, lock-up periods, high-water mark

the skill you've paid us such fat fees for. Upon reflection, we have decided that we're actually much better at giving you "smart beta".' (The Economist, February 18, 2012) 
protection, use of leverage, and offshore operation. Thus, we control for all these factors while investigating the impact of various market conditions on fund flow sensitivities.

We find that prevailing market conditions significantly change the shape of flow-performance relation as well, even after controlling for multiple aforementioned cross-sectional fund characteristics. ${ }^{6}$ A generally concave flow-performance relationship is detected, but flow sensitivities change significantly when market conditions are examined separately. We further find that hedge fund flows are responsive to past performance asymmetrically. In particular, market conditions in general affect flow sensitivities among the worst and best performing funds. This observation is more evident during up- and downvolatile markets. However, fund investors seem to adopt different investment strategies in these two market conditions - they reduce investment in past winners in the best and worst fund performing groups when markets are up and volatile, and they are more sensitive to fund performance in the worst fund performing group during down-volatile markets. When market is quiet, there is almost no change in flow-performance relation between up and down markets. Flow sensitivities to medium performers stay largely the same (and significant) throughout all market states. When we use a refined fund sample to explore the flow-performance relationship, the findings are generally similar that market volatility matters for investment behavior and both upside and downside volatilities influence investors' decision making.

We also examine whether hedge fund investors have the capability to identify outperforming hedge funds, and if so, whether such ability changes with market conditions. Although the empirical evidence from the mutual fund industry is largely mixed, mutual fund investors seem to have the ability to identify funds that will subsequently outperform. ${ }^{7}$ Since hedge fund investors may behave differently, similar studies have been conducted to examine the smart-money effect in the hedge fund industry, and the empirical evidence is also mixed. ${ }^{8}$ Our paper documents the existence of a general smart-money effect in the hedge fund industry conditional on the market conditions. Except volatile markets (both up-volatile and down-volatile), we find that smart money effect exists in all other market conditions over both 3- and 12-month investment horizons. This indicates that when market is calm and relatively predictable, fund investors are capable of identifying good managers and can benefit from good performance at least for a short period of time. Market volatility does affect the ability of selecting good performers by hedge fund investors.

\footnotetext{
${ }^{6}$ In unreported tables, we also add restriction periods, such as redemption period and required advanced notice period for redemptions, to control for the additional effect of share restrictions in the regressions. Our results are robust. Variable selections are detailed in the data section.

${ }^{7}$ See, for example, Gruber (1996), Zheng (1999), Sapp and Tiwari (2004), Frazzini and Lamont (2008), Keswani and Stolin (2008), and Ivkovi and Weisbenner (2009).

${ }^{8}$ See Baquero and Verbeek (2009), Ding et al. (2009), Ozik and Sadka (2009), and Wang and Zheng (2008).
} 
Lastly, we investigate fund performance persistence over the same 3- and 12-month horizons conditional on the market status. We find that hedge fund performance persists over both 3- and 12month periods in all market conditions, with the level of persistence significantly strengthened during quiet markets, and weakened during volatile markets. Both upside and downside volatilities affect performance persistence negatively. Thus, fund performance in the volatile markets cannot be used to predict future hedge fund performance. This is consistent with Busse's (1999) findings in mutual fund literature. Given that the pattern of performance persistence is matched with that of "smart money" effect under various market conditions, the smart money effect in the hedge fund industry is largely driven by fund performance persistence in quiet markets. Although it is not clear whether upside market volatility is as important as downside volatility in explaining investor behaviors, our overall results provide evidence that market conditions play a role in the investment process, that market volatility affects not only investors' ability to pick winner funds but also fund managers' ability to deliver alpha, and that both upside and downside volatilities influence investment behaviors and hedge fund performance. Thus, the strategy of chasing winners and smart money effect do not work during volatile markets, particularly due to the lack of persistency in fund performance. Fund performance can be used as a good indicator of management ability, but it is no longer the case when market becomes volatile.

Our study makes several contributions to the literature. First, we complement previous studies to show that market conditions influence investor behavior and flow-performance relationship in the hedge fund industry. Using mutual fund samples, Luo (2003), Ederington and Golubeva (2009), and Ferson and Kim (2012) show that stock market volatility negatively affects equity fund flows. We show this observation also exists in the hedge fund industry. Ferson and Kim further indicate that fund flows predict future economic conditions. In our study, investors' predictability only exists during the quiet markets. Sirri and Tufano (1998) show that lower search costs increase fund flows to performance sensitivity. Huang, Wei and Yan (2007) explicitly indicate that lower participation costs make investors more sensitive to medium performance and less sensitive to high performance. Ding et al. (2009) demonstrate that the flow-performance relation varies with share restrictions. We show that market conditions affect the flow-performance relationship among the high and low performance fund groups but have relatively little impact on the medium performance fund group.

Second, we demonstrate that the volatility in both up and down markets affects investment behaviors of hedge fund investors. Similar to Luo's (2003) findings in the mutual fund industry, hedge fund investors put less money into hedge funds during up- and down-volatile markets. They also change their investment strategies and become less sensitive to fund past performance in the up-volatile markets. Although previous literature suggests that upside volatility may not be important (Rom and Ferguson, 
1993,1994; and Nawrocki, 1999), our results demonstrate that, like downside volatility, upside volatility does have a significant negative impact on the investors' ability to pick outperforming hedge funds and fund managers' ability to outperform benchmarks. The upside volatility also weakens hedge fund managers' capability in providing better risk-adjusted returns. It is not clear how important upside volatility should play a role in investment; nevertheless, our results suggest that upside volatility affects investor behaviors.

Third, we add to a growing body of working papers that examine the existence of smart money effect in the hedge fund industry. Ding et al. (2009) document a smart-money effect in the universe of hedge funds, while Ozik and Sadka (2009) argue that the smart-money effect predominantly stems from highflow-impact funds. On the other hand, Wang and Zheng (2008) find that the smart-money effect does not exist in the hedge fund industry, at least in the short run. Similarly, Baquero and Verbeek (2009) do not find supporting evidence of smart money effect in their study either. Our study differs from these papers on several dimensions. We show that market conditions may be the reason to cause the mixed findings. After we control for the market conditions, smart money exists when market is relatively calm and predictable. However, the smart money effect disappears when market becomes volatile. We further demonstrate the source of the smart money for hedge funds is likely from the performance persistence. Agarwal and Naik (2000) find that hedge fund performance persists at the quarterly horizon. Our paper expands the literature to provide evidence to show that hedge funds can provide persistent performance at maximum of one year horizon after controlling for the market conditions.

The rest of the paper is organized as follows. Next section describes the data and methodology used in our analyses. Section 3 discusses empirical findings of the flow-performance relationship under different market conditions, followed by smart-money tests in Section 4. Section 5 addresses the performance persistence and Section 6 concludes.

\section{Data and Methodology}

\section{A. Data}

The hedge fund sample used in this study comes from Lipper-TASS, one of the leading hedge fund research databases. ${ }^{9}$ The complete database includes more than 9,000 hedge funds (both active and inactive), and reports detailed information about monthly fund returns, assets under management (AUM), as well as other fund characteristics such as fund style, country of operation, minimum investment amount, management and incentive fees, and lockup period for individual hedge funds. Our sample

\footnotetext{
${ }^{9}$ We also use CISDM hedge fund database as our hedge fund sample. Results are qualitatively similar.
} 
consists of all individual hedge funds in U.S. Dollar denomination and with minimum 24 monthly return data. A total of 5,254 individual funds have met the criteria during the period of 1994 to 2009. As shown in the left panel of Table 1, our final sample covers 12 investment styles including convertible arbitrage, dedicated short bias, emerging markets, equity market neutral, event driven, fixed income arbitrage, global macro, long/short equity hedge, managed futures, option strategy, multi-strategy, and others. Among these investment styles, long/short equity hedge funds account for $37.5 \%(1,968)$ of the sample, followed by emerging markets, event driven, and managed futures funds, each accounting for about $10 \%$ of the sample. We further investigate countries that funds are domiciled, and find that funds in our sample are from 40 different countries. The top 13 countries are presented in the right panel of Table 1, and it is worth noting that more than $90 \%$ (or 4,747 funds) are located in the following four countries: United States (38\% of the sample), Cayman Islands (38\%), British Virgin Islands (9\%), and Bermuda (6\%).

\section{Table 1: Summary of Hedge Fund Investment Styles and Domicile Countries}

The table reports the summary of investment styles and domicile countries of individual hedge funds from LipperTASS database. The sample includes both live and graveyard funds which are in U.S. dollar denomination and have a minimum of 24 monthly return data available. Funds of funds are excluded. Sample period is from January 1994 to December 2009.

\begin{tabular}{|c|c|c|c|c|c|c|}
\hline Investment Style & $\mathrm{N}$ & $\%$ & Domicile Country & $\mathrm{N}$ & $\%$ & Cum. \% \\
\hline Long/Short Equity Hedge & 1968 & $37.46 \%$ & United States & 1994 & $38.09 \%$ & $38.09 \%$ \\
\hline Emerging Markets & 541 & $10.30 \%$ & Cayman Islands & 1966 & $37.55 \%$ & $75.64 \%$ \\
\hline Event Driven & 540 & $10.28 \%$ & British Virgin Islands & 473 & $9.04 \%$ & $84.68 \%$ \\
\hline Managed Futures & 535 & $10.18 \%$ & Bermuda & 314 & $6.00 \%$ & $90.68 \%$ \\
\hline Multi-Strategy & 402 & $7.65 \%$ & Bahamas & 130 & $2.48 \%$ & $93.16 \%$ \\
\hline Global Macro & 319 & $6.07 \%$ & Ireland & 83 & $1.59 \%$ & $94.75 \%$ \\
\hline Equity Market Neutral & 318 & $6.05 \%$ & Guernsey & 67 & $1.28 \%$ & $96.03 \%$ \\
\hline Fixed Income Arbitrage & 207 & $3.94 \%$ & Luxembourg & 57 & $1.09 \%$ & $97.12 \%$ \\
\hline Convertible Arbitrage & 191 & $3.64 \%$ & Canada & 33 & $0.63 \%$ & $97.75 \%$ \\
\hline Other & 172 & $3.27 \%$ & Netherlands Antilles & 27 & $0.52 \%$ & $98.26 \%$ \\
\hline Dedicated Short Bias & 39 & $0.74 \%$ & Jersey & 24 & $0.46 \%$ & $98.72 \%$ \\
\hline Options Strategy & 15 & $0.29 \%$ & Mauritius & 16 & $0.31 \%$ & $99.03 \%$ \\
\hline Undefined & 7 & $0.13 \%$ & United Kingdom & 7 & $0.13 \%$ & $99.16 \%$ \\
\hline Total & 5254 & & & 5235 & & \\
\hline
\end{tabular}

Table 2 reports summary statistics of multiple hedge fund characteristics over the whole sample period. Fund characteristics include assets under management (AUM, in millions of U.S. dollars), minimum investment amount (in millions of U.S. dollars), management fees (\%), incentive fees (\%), lockup period (in months), fund age (in years), and four dummy variables indicating whether a fund has a high-water mark, leverage, offshore operation, and manager's personal capital invested in the fund. The high-water mark dummy is defined as taking the value of 1 if a fund imposes high-water mark protection for investors, and 0 otherwise. The leverage dummy is defined as taking the value of 1 if a fund is leveraged, and 0 otherwise. The offshore operation dummy takes the value of 1 if a fund is operated in a 
country other than United States, and 0 otherwise. The personal capital dummy takes the value of 1 if a fund manager has personal capital invested in the fund assets, and 0 otherwise. These variables have been shown in the previous research to have an impact on both fund performance and flow-performance relation. Goetzmann, Ingersoll and Ross (2003) find that high-water mark, return volatility, incentive contract, and management fees affect fund performance. Agarwal, Daniel and Naik (2009) demonstrate that incentive contracts, managerial ownership and high-water mark are related to superior performance. Aragon, Liang and Park (2008) find onshore and offshore hedge funds have different behaviors. Fund size (AUM) is included, as Berk and Green (2004) document decreasing returns to scale in fund industry. ${ }^{10}$

Table 2: Summary Statistics of Hedge Fund Characteristics

The table reports summary statistics of hedge funds' characteristics for the whole sample period from January 1994 to December 2009. Fund characteristics include assets under management (AUM, in \$ million), minimum investment (in \$ million), management fees (in \%), incentive fees (in \%), lockup period (in months), fund age (in years), and dummy variables indicating whether the fund imposes high-water mark provision, whether the fund is leveraged, whether the fund is operating outside the U.S. (offshore), and whether the fund has managers' personal capital invested in the fund asset. The mean, standard deviation (SD), lower quartile (Q1), median (Median), and upper quartile (Q3) of individual characteristics are reported for the whole sample period.

\begin{tabular}{llllll}
\hline \hline Variables & Mean & SD & Q1 & Median & Q3 \\
\hline AUM (MM) & 125.15 & 368.67 & 9.42 & 31.74 & 101.75 \\
Minimum investment (MM) & 1.11 & 14.15 & 0.10 & 0.50 & 1.00 \\
Management fees (\%) & 1.48 & 0.68 & 1.00 & 1.50 & 2.00 \\
Incentive fees (\%) & 18.29 & 5.72 & 20.00 & 20.00 & 20.00 \\
Lockup period (months) & 3.56 & 6.56 & 0.00 & 0.00 & 6.00 \\
Age (years) & 6.38 & 4.13 & 1.83 & 5.17 & 8.25 \\
HighWaterMark (dummy) & 0.66 & 0.47 & 0.00 & 1.00 & 1.00 \\
Leverage (dummy) & 0.63 & 0.48 & 0.00 & 1.00 & 1.00 \\
Offshore (dummy) & 0.62 & 0.49 & 0.00 & 1.00 & 1.00 \\
Personal capital (dummy) & 0.33 & 0.47 & 0.00 & 0.00 & 1.00 \\
\hline \hline
\end{tabular}

Over the whole sample period, the hedge fund industry has an average of $\$ 125.2$ million assets under management and a standard deviation of \$368.7 million in size. Hedge funds on average require \$1.11 million of minimum investment amounts, with a standard deviation of $\$ 14.2$ million. Hedge funds in general charge $1.48 \%$ of fund asset as expenses. The average lockup period is 3.6 months with a standard deviation of 6.6 months. $66 \%$ of the funds offer high-water mark protections for their investors, and the incentive fee charged by an average fund is $18.3 \%$ (with $5.7 \%$ standard deviation). A typical $20 \%$ incentive fee is charged by at least half of individual funds (from lower quartile Q1 to upper quartile Q3). The average age of hedge funds in our sample is 6.4 years, with standard deviation of 4.1 years. $63 \%$ of

\footnotetext{
${ }^{10} \mathrm{We}$ also have qualitatively the same results when removing funds that are less than $\$ 10 \mathrm{M}$ and excluding the first 12 months of fund returns (Fung and Hsieh, 2000). Aggarwal and Jorion (2010) demonstrate that the median backfill period is 480 days. Fung and Hsieh (2000) also report the median is 343 days for the backfill period. Our adjustment should be able to minimize the backfill bias and omitted returns.
} 
funds are leveraged, and $62 \%$ of funds are operating outside the United States. In addition, about 33\% of funds have their managers' personal capital invested in the fund assets. ${ }^{11}$

Two issues are related to our study. Ding et al. (2009), and Baba and Goko (2009) argue that share restrictions affect the shape of flow-performance relation and hedge funds' survival probability. Share restrictions include lockup period, redemption period, advance notice period, subscription period, capacity constrained, open to investment, and onshore operation. Another concern is the issue of the omitted time-invariant determinant of fund flows. Since our purpose is to investigate whether market conditions affect flow-performance relation, in our later tests, we use lockup period and offshore operation in addition to lagged fund flow to control for share restrictions and some unobserved factors which may be related to fund flows but not in the regressions. This simplifies regression specifications and reports. ${ }^{12}$ Our baseline regression model reports a concave relation between fund flow and fund performance which is consistent with Ding et al.'s findings in the presence of share restrictions. Considering that investors may be risk-averse and that volatile funds have fewer restrictions as evidenced by Ding et al., we also control for fund performance volatility.

Table 3 describes summary statistics of sample monthly raw returns (in \%) and fund flows (in \%) for the whole sample period and multiple subperiods. Summary statistics of each measure include the sample mean, standard deviation (SD), lower quartile (Q1), median, and upper quartile (Q3). The monthly flow (in \%) is defined as the monthly fund flow in dollar amount scaled by the previous month-end asset value. That is,

Flow $_{i, t}=\frac{A U M_{i, t}-A U M_{i, t-1} \times\left(1+R_{i, t}\right)}{A U M_{i, t-1}}$

where $A U M_{i, t}$ represents the value of assets under management of fund $i$ at month $t$, and $R_{i, t}$ is the return of fund i during month t. In our flow calculations, we notice that some funds report their AUM quarterly or semiannually while reporting multiple zero monthly AUMs between two positive reporting values. These zero AUM values are treated as missing when applying Equation (1). In addition, some funds have reported the same AUM for two consecutive months, a rare occasion that fund flow during a given month exactly offsets its asset growth in value. Attributing such observations to possible stale reporting, we only

\footnotetext{
${ }^{11}$ In unreported tables, we further investigate the sample by breakdowns of different market conditions, and by subperiods according to significant market events. All fund characteristics remain qualitatively the same.

${ }^{12}$ In unreported tables, we also add restriction periods, such as redemption period, required advanced notice period for redemptions, as well as other share restrictions related variables to control for share restrictions in the regressions. Results in general are qualitatively similar. However, most coefficient estimates in the regressions for these variables are insignificant.
} 
include flows calculated from two consecutive AUM amounts that are not identical. To ensure the quality of our data analysis employing fund flow variable, we further Winsorize fund flows at $5 \%$ cutoff point to remove extremely large or small values that might be due to reporting errors. ${ }^{13}$

\section{Table 3: Summary Statistics of Hedge Fund Monthly Returns and Flows}

The table reports summary statistics of hedge fund sample from TASS database for the whole period and multiple subperiods from January 1994 to December 2009. In addition to the number of months (in parentheses) for each period, the table reports mean, standard deviation (SD), lower quartile (Q1), median, and upper quartile (Q3) of monthly fund raw returns (in \%) and monthly fund flows (in \%), respectively. Monthly fund flow is defined as the change of monthly net assets scaled by the previous month-end asset value. Multiple subperiods include yearly breakdown, up/down, quiet/volatile markets, and 4 subperiods sorted by combinations of up/down and quiet/volatile market conditions (that is, up-quiet, up-volatile, down-quiet, and downvolatile). Up (down) market period is defined as the month when equity market return in excess of 1-month Treasury-bill return is positive (negative). Quiet (volatile) market is defined as the month when the average daily volatility of stock market in a month is less(more) than average daily volatility of the whole sample period.

\begin{tabular}{|c|c|c|c|c|c|c|c|c|c|c|}
\hline & \multicolumn{5}{|c|}{ Monthly Return (\%) } & \multicolumn{5}{|c|}{ Monthly Flow (\%) } \\
\hline & Mean & SD & Q1 & Median & Q3 & Mean & SD & Q1 & Median & Q3 \\
\hline Whole sample & 0.773 & 0.967 & 0.341 & 0.711 & 1.129 & 0.054 & 0.141 & 0.005 & 0.030 & 0.067 \\
\hline By year & & & & & & & & & & \\
\hline 1994 & 0.216 & 2.111 & -0.706 & 0.272 & 0.914 & 0.059 & 0.191 & -0.003 & 0.014 & 0.072 \\
\hline 1995 & 1.750 & 2.478 & 0.747 & 1.442 & 2.483 & 0.054 & 0.177 & -0.007 & 0.010 & 0.055 \\
\hline 1996 & 1.635 & 2.044 & 0.826 & 1.483 & 2.321 & 0.068 & 0.184 & -0.003 & 0.018 & 0.078 \\
\hline 1997 & 1.548 & 2.068 & 0.721 & 1.368 & 2.233 & 0.079 & 0.213 & 0.001 & 0.025 & 0.094 \\
\hline 1998 & 0.596 & 2.691 & -0.294 & 0.748 & 1.760 & 0.053 & 0.231 & -0.005 & 0.013 & 0.057 \\
\hline 1999 & 2.391 & 3.685 & 0.559 & 1.529 & 3.661 & 0.054 & 0.208 & -0.007 & 0.009 & 0.056 \\
\hline 2000 & 0.824 & 2.829 & -0.065 & 0.954 & 1.804 & 0.054 & 0.239 & -0.006 & 0.012 & 0.059 \\
\hline 2001 & 0.625 & 2.507 & 0.003 & 0.640 & 1.344 & 0.077 & 0.396 & -0.004 & 0.014 & 0.064 \\
\hline 2002 & 0.314 & 1.745 & -0.402 & 0.347 & 1.060 & 0.063 & 0.263 & -0.006 & 0.010 & 0.058 \\
\hline 2003 & 1.608 & 2.176 & 0.477 & 1.198 & 2.287 & 0.080 & 0.371 & -0.002 & 0.018 & 0.072 \\
\hline 2004 & 0.786 & 1.270 & 0.219 & 0.638 & 1.201 & 0.072 & 0.259 & -0.001 & 0.020 & 0.070 \\
\hline 2005 & 0.849 & 1.538 & 0.224 & 0.644 & 1.173 & 0.046 & 0.249 & -0.012 & 0.007 & 0.046 \\
\hline 2006 & 1.149 & 1.509 & 0.527 & 0.963 & 1.489 & 0.049 & 0.292 & -0.007 & 0.011 & 0.050 \\
\hline 2007 & 1.082 & 2.098 & 0.240 & 0.851 & 1.643 & 0.043 & 0.183 & -0.006 & 0.009 & 0.047 \\
\hline 2008 & -1.502 & 3.075 & -2.803 & -1.138 & 0.319 & 0.010 & 0.163 & -0.026 & -0.002 & 0.020 \\
\hline 2009 & 1.432 & 5.220 & 0.037 & 1.008 & 2.541 & -0.006 & 0.138 & -0.030 & -0.005 & 0.011 \\
\hline Up market (118) & 1.732 & 1.874 & 0.698 & 1.334 & 2.442 & 0.054 & 0.176 & 0.002 & 0.026 & 0.065 \\
\hline Down market (74) & -0.584 & 2.269 & -1.481 & -0.250 & 0.515 & 0.052 & 0.195 & -0.001 & 0.021 & 0.060 \\
\hline Quiet market (148) & 1.220 & 1.286 & 0.568 & 1.010 & 1.633 & 0.060 & 0.150 & 0.005 & 0.032 & 0.073 \\
\hline Volatile market (44) & -0.683 & 2.921 & -1.452 & -0.204 & 0.666 & 0.040 & 0.227 & -0.011 & 0.006 & 0.042 \\
\hline Up-quiet (101) & 1.843 & 2.012 & 0.778 & 1.441 & 2.535 & 0.055 & 0.143 & 0.003 & 0.027 & 0.068 \\
\hline Up-volatile (17) & 0.876 & 4.226 & -0.540 & 0.735 & 2.320 & 0.038 & 0.316 & -0.014 & 0.002 & 0.036 \\
\hline Down-quiet (47) & 0.006 & 2.069 & -0.749 & 0.146 & 0.750 & 0.067 & 0.227 & 0.001 & 0.025 & 0.072 \\
\hline Down-volatile (27) & -1.505 & 4.183 & -3.044 & -0.836 & 0.561 & 0.039 & 0.257 & -0.011 & 0.006 & 0.042 \\
\hline
\end{tabular}

As shown in the table, hedge fund managers generate an average monthly return of $0.77 \%$ (or $9.28 \%$ per annum) during the January 1994 to December 2009 period, with a standard deviation of 0.97\%. In contrast, the U.S. equity market as a whole delivers an average monthly return of $0.74 \%$ (or $8.86 \%$ per

\footnotetext{
${ }^{13}$ We also Winsorize our data at $10 \%$ level and the results remain qualitatively the same.
} 
annum) during the same period, with a much larger standard deviation of $4.66 \% .{ }^{14}$ The comparison suggests that hedge funds perform slightly better than the equity market, but with much smaller variations. When inspected on the yearly basis, performance of individual funds peaked to an average monthly return of $2.39 \%$ (or $28.69 \%$ per annum) in 1999 with a standard deviation of $3.69 \%$, and plunged to a $-1.50 \%$ average monthly return (or $-18.0 \%$ per annum) in 2008 with a standard deviation of $3.08 \%$. On the other hand, the hedge fund industry has an average monthly net growth of $0.05 \%$ in assets under management, with standard deviation of $0.14 \%$ during the sample period. The monthly flow reached to a high of $0.08 \%$ in 2003, and a low of $-0.01 \%$ in 2009 , after the financial crisis stormed the hedge fund industry.

To better understand the swinging year-by-year patterns of returns and flows, we take a closer look at the subperiods of our sample. That is, we divide our sample according to the following market conditions: up, down, quiet, and volatile markets. Here an up (down) market period is defined as the month when equity market return in excess of 1-month Treasury-bill return is positive (negative). ${ }^{15}$ A quiet (volatile) market period is defined as the month when the average daily equity market return volatility is less (more) than average volatility of the whole sample period. ${ }^{16}$

Summary statistics on the subperiods suggest that individual hedge funds generate much better raw returns when stock market rallies. In particular, hedge funds generate an average of $1.73 \%$ monthly return over the 118 up-market months, while producing a negative average return (-0.58\%) during the 74 months of down markets. Interestingly, over both markets individual hedge funds have attracted very similar levels of average monthly flows, with flows in up markets $(0.054 \%)$ slightly higher than that in down markets $(0.052 \%)$. In contrast, quiet and volatile markets present a very similar pattern in returns like up and down markets, but different in fund flows. Hedge fund managers on average seem to perform better during quiet markets than volatile markets. Over the 148 quiet-market months, an average of $1.22 \%$ monthly return is generated by hedge fund managers, much better than the negative average return (-0.68\%) over the 44 volatile market months. On the other hand, an average hedge fund attracts more monthly flows in quiet markets $(0.06 \%)$ than in volatile markets $(0.04 \%)$. The difference of fund flows between quiet and volatile markets is significant at conventional levels.

\footnotetext{
${ }^{14}$ We use the CRSP value-weighted market return, including all dividend distributions, as the proxy of equity market returns.

${ }^{15}$ In an alternative setting, we define up (down) market period as the month when equity market return in excess of 1-month Treasury-bill return exceeds the previous market excess return by more (less) than $1 \%$. The summary statistics are very similar.

${ }^{16}$ The volatile market condition dummy used in our study is defined according to the realized market volatility during the sample period. We also looked at an alternative definition according to the CBOE's VIX index value, or implied volatility. Our results remain qualitatively the same.
} 
To further explore this issue, we sort our sample by both up/down and quiet/volatile market conditions, thus dividing the sample period into the following 4 subperiods: up-quiet (101 months), upvolatile (17 months), down-quiet (47 months), and down-volatile market periods (27 months). As shown in the table, hedge fund managers generate the best raw returns in up-quiet markets $(1.84 \%$ monthly, or $22.1 \%$ per annum), while the worst during down-volatile periods ( $-1.51 \%$ monthly, or $-18.1 \%$ per annum), a return difference of $3.35 \%$ per month (or $40.2 \%$ per annum). At the same time, hedge funds receive the highest flows during down-quiet market months (0.067\%) and the lowest during up-volatile months $(0.038 \%)$. The fund flows for up-volatile markets are even lower than down-volatile markets. It is interesting to note that hedge funds actually earn an average return of $0.88 \%$ in the up-volatile markets (the second highest return among all market conditions). This indicates that hedge fund investors may care about upside volatility. If upside volatility is not important for investors, we should not see a significant change of fund flows in the table between up-quiet and up-volatile markets or down-quiet and up-volatile markets.

Our preliminary results demonstrate that hedge fund investors have different behaviors in each market condition. They especially invest less when markets are volatile. Such a notable difference in hedge fund returns and flows over different subperiods deserves a more detailed investigation of the flowperformance relationship, which we will actively pursue in the subsequent sections.

\section{B. Hedge Fund Performance}

In addition to raw monthly returns reported by the funds, we measure fund performance using riskadjusted returns from an augmented eight asset-based style factor model based on Fung and Hsieh (2001, 2004).

The risk-adjusted performance of individual hedge funds is evaluated using the 8-factor model as follows:

$$
\begin{aligned}
r_{i, t}=\alpha_{i} & +\beta_{i, 1} \times \text { PTFSBD }_{t}+\beta_{i, 2} \times \text { PTFSFX }_{t}+\beta_{i, 3} \times \text { PTFSCOM }_{t}+\beta_{i, 4} \times S \& P_{t}+\beta_{i, 5} \times \text { SizeSpread }_{t} \\
& +\beta_{i, 6} \times \text { BondMarket }_{t}+\beta_{i, 7} \times \text { CreditSpread }_{t}+\beta_{i, 8} \times \text { MSCIEM }_{t}+\varepsilon_{i, t}
\end{aligned}
$$

where $r_{i, t}$ is fund i's return at time $t$ in excess of the risk free rate, PTFSBD, PTFSFX, and PTFSCOM are trend-following risk factors constructed by Fung and Hsieh (2001) to measure trend-following strategies in bonds, foreign currencies, and commodities, respectively. ${ }^{17} \mathrm{~S} \& \mathrm{P}$ and SizeSpread are equity-oriented risk factors, measured by S\&P 500 market index monthly return and Russell 2000 index monthly return in

\footnotetext{
${ }^{17}$ The trend-following factors are obtained from the link: http://faculty.fuqua.duke.edu/dah7/DataLibrary/TF-Fac.xls.
} 
excess of S\&P 500 return, respectively. BondMarket and CreditSpread are bond-oriented risk factors, measured by monthly change in the 10-year treasury constant maturity yield and monthly change in the Moody’s Baa yield less 10-year treasury constant maturity yield, respectively. MSCIEM is the MSCI Emerging Market index monthly total return, and is included into the model given the fact that more than $10 \%$ of the funds in our sample are involved with emerging markets investments, thus exposed to the emerging market risk. $\varepsilon_{i, t}$ is the error term, uncorrelated with these eight factors. $\beta_{\mathrm{i}, 1} \ldots \beta_{\mathrm{i}, 8}$ are risk factor loadings for fund i. As a result, $\alpha_{\mathrm{i}}$ represents the risk-adjusted performance for fund $\mathrm{i}$.

\section{Table 4: Risk-Adjusted Fund Performance and Market Conditions}

The table reports the cross-sectional average of monthly risk-adjusted returns for the whole sample period and by different market states. Risk-adjusted returns $(\alpha$, in \%) are estimated from the following augmented 8 -factor model:

$$
\begin{aligned}
& r_{i, t}=\alpha_{i}+\beta_{i, 1} \times \text { PTFSBD }_{t}+\beta_{i, 2} \times \text { PTFSFX }_{t}+\beta_{i, 3} \times \text { PTFSCOM }_{t}+\beta_{i, 4} \times S \& P_{t}+\beta_{i, 5} \times \text { SizeSpread }_{t} \\
& \quad+\beta_{i, 6} \times \text { BondMarket }_{t}+\beta_{i, 7} \times \text { CreditSpread }_{t}+\beta_{i, 8} \times \text { MSCIEM }_{t}+\varepsilon_{i, t}
\end{aligned}
$$

where $r_{t}$ is fund i's return at time $t$ in excess of the risk free rate, PTFSBD, PTFSFX, and PTFSCOM are trendfollowing risk factors constructed by Fung and Hsieh (2001) to measure trend-following strategies in bonds, foreign currencies, and commodities, respectively. S\&P is the S\&P 500 market index monthly return. SizeSpread is the Russell 2000 index monthly return in excess of S\&P 500 return. BondMarket is the monthly change in the 10-year treasury constant maturity yield. CreditSpread is the monthly change in the Moody's Baa yield less 10-year treasury constant maturity yield. MSCIEM is the MSCI Emerging Market index monthly total return. $\varepsilon_{i, t}$ is the error term, uncorrelated with these seven factors. For each market state, mean, median, and standard deviation of fund $\alpha$ are reported, as well as the fraction of funds with significant ( $5 \%$ level) positive and negative $\alpha$ values. See Table 3 for definitions of various market conditions. Sample period is from January 1994 to December 2009.

\begin{tabular}{lrrrrrr}
\hline \hline Markets & Mean & $t$-stat & Median & STD & $\alpha>0(\%)$ & $\alpha<0(\%)$ \\
\hline Whole sample & 0.43 & 1.22 & 0.37 & 1.17 & 25.80 & 2.13 \\
& & & & & & \\
Up market & 0.48 & 0.62 & 0.43 & 1.70 & 12.64 & 5.50 \\
Down market & 0.48 & 0.93 & 0.43 & 1.25 & 17.06 & 4.89 \\
& & & & & & \\
Quiet market & 0.53 & 1.43 & 0.42 & 1.29 & 24.56 & 5.31 \\
Volatile market & 0.33 & -0.24 & 0.27 & 1.67 & 3.93 & 29.63 \\
& & & & & & \\
Up-quiet & 0.63 & 0.60 & 0.40 & 2.15 & 6.72 & 16.92 \\
Up-volatile & 0.70 & 0.77 & 0.53 & 2.11 & 2.09 & 61.97 \\
Down-quiet & 0.61 & 1.06 & 0.48 & 1.53 & 18.03 & 11.50 \\
Down-volatile & -0.09 & 0.25 & 0.00 & 2.43 & 0.24 & 75.06 \\
\hline \hline
\end{tabular}

Table 4 reports the cross-sectional monthly average alphas for the whole sample period and in various market states. As shown in the table, an average hedge fund yields positive monthly alpha of $0.43 \%$ (or $5.16 \%$ per annum) with median value of $0.37 \%$ (or $4.44 \%$ per annum). Although statistically insignificant, the positive monthly risk-adjusted return generated by the hedge fund industry is in sharp contrast to the mutual fund industry, which generates average alphas very close to zero. Over the whole sample period, $25.8 \%$ of hedge funds deliver positive alphas that are statistically significant at the $5 \%$ level, while only 
2.1\% of funds yield significantly (at 5\% level) negative alphas. The evidence from the whole sample period seems consistent with the notion that hedge funds deliver alpha regardless market conditions.

Interesting observations emerge when fund performance is examined in different market conditions separately. Although hedge funds generate almost identical positive alphas of $0.48 \%$ (or $5.76 \%$ per annum) in both up and down markets, about $17 \%$ of funds generate significantly positive alphas in the down market, compared to $12 \%$ in the up market. The evidence of identical performance in both markets with more funds generating superior performance and fewer funds generating inferior performance in down markets tends to suggest that hedge funds can offer good protection for investors when the market is sliding.

A very different pattern is revealed, however, when the fund performance is investigated in quiet and volatile markets separately. The average alpha of $0.53 \%$ (or $6.36 \%$ per annum) generated in quiet markets is much higher than the mean alpha of $0.33 \%$ (or 3.96\% per annum) in volatile markets, a difference of $0.20 \%$ per month (or $2.4 \%$ per annum). Furthermore, the percent of funds that deliver significant positive alphas in quiet markets (24.6\%) is much higher than in volatile markets (3.9\%), while poorly performing funds in volatile markets (29.6\%) substantially outnumber those in quiet markets (5.3\%). Since volatile markets seem to have a more negative effect on fund performance than down markets, we then turn to a more detailed investigation using combinations of various market conditions.

The further breakdown by a combination of up/down and quiet/volatile market conditions indeed offers some more interesting observations. The best performance of hedge funds occurs in up-volatile markets with a mean of $0.70 \%$, followed by up-quiet markets $(0.63 \%)$, down-quiet markets $(0.61 \%)$, and down-volatile markets (-0.09\%). It is notable that individual hedge funds generate similar positive riskadjusted performance in the first three market conditions, while the worst and the only negative average performance comes from down-volatile markets. In particular, about $75 \%$ of funds produce significantly negative alphas in down-volatile markets, while only $0.24 \%$ of funds generate significantly positive alphas in the same market. Up-volatile markets have the second worst fund performance in our sample period, with $62 \%$ of funds generating significantly negative alphas, and only $2.1 \%$ generating significantly positive alphas. In contrast, down-quiet markets seem to observe the most reliable hedge fund performance among individual hedge funds, with $18 \%$ of funds generating significantly positive alphas, and $11.5 \%$ generating significantly negative alphas.

Our findings tend to suggest that hedge fund managers in general cannot beat the market and offer effective protections when the market is in extreme conditions (such as down-volatile), and that the downside risk protection observed in the down markets mainly comes from down-quiet periods. Overall 
results from Tables 3 and 4 seem to support Roy’s (1952) safety first principle. During down-volatile markets, hedge funds generate unreliable risk-adjusted returns and the fund flows are lower. However, the same observation also applies to up-volatile markets. In the up-volatile markets, hedge funds could not offer reliable performance for their investors and fund investors restrain their investment from hedge funds (the lowest fund flows) even though the average of risk-adjusted returns across all hedge funds in this market condition is the highest among all market conditions.

\section{Flow Sensitivities to Past Performance}

Summary statistics from the previous section indicate very different patterns for both fund performance and flows under different market conditions. Reduced fund flows during up- and down-volatile markets are the evidence indicating that volatility in the up and down markets matters for investors. However, it is not clear whether investors perceive the same between upside and downside volatilities while hedge funds receive similar fund flows in both market conditions. It is possible that upside and downside volatilities have different effects on the investors' behavior. In this section, we examine the relationship between hedge fund flows and past performance in various market conditions using a piecewise linear regression model to offer more details about how fund investors change their investment strategies pertaining to market conditions or they just reduce investment when markets become volatile.

Previous studies document that fund investors learn about fund management's ability from past fund performance (e.g., Sirri and Tufano, 1998; and Berk and Green, 2004). This is because fund investors cannot directly observe fund managers' skill, and managers' ability and investment strategy should not change during a certain time period. Thus, fund investors first try to evaluate funds' management quality from operating performance, consider current situation, estimate possible future outcomes and then, invest their money (Lynch and Musto, 2003; and Berk and Green, 2004). How fund investors interpret fund past performance and relate it to the future fund return and what the risk and investment costs could be are essential to the flow-performance relationship. Therefore, using the flow-performance sensitivity to investigate fund investors' behavior offers better understanding about some subtle yet important attitudes that investors have toward overall volatility, and each of upside and downside volatilities than using simple relation between market conditions and fund flows.

We investigate the flow-performance sensitivities in a piecewise linear regression model setting similar to Sirri and Tufano (1998). For a given month t, we first assign fractional performance rank 
(Rankt) from 0 to 1 based on the past performance of individual funds, and then define three performance groups (Low, Mid, and High) as follows: ${ }^{18}$

$$
\begin{array}{ll}
\operatorname{Low}_{t} & =\operatorname{Min}\left(1 / 3, \operatorname{Rank}_{\mathrm{t}}\right) \\
\text { Mid }_{t} & =\operatorname{Min}\left(1 / 3, \operatorname{Rank}_{\mathrm{t}}-\operatorname{Low}_{\mathrm{t}}\right) \\
\operatorname{High}_{\mathrm{t}} & =\operatorname{Min}\left(1 / 3, \operatorname{Rank}_{\mathrm{t}}-\operatorname{Low}_{\mathrm{t}}-\operatorname{Mid}_{\mathrm{t}}\right)
\end{array}
$$

Here the fund performance is measured by either average raw returns or risk-adjusted returns using the augmented 8-factor model over past 12 months. Fund flow is then regressed against lagged performance ranks to examine flow sensitivities at different levels of performance. Since our main interest is on the impact of a particular market condition on the flow-performance relationship, we interact with performance rank on various market condition dummy variables to capture this effect. The general piecewise linear regression model is thus formulated as follows:

$$
\begin{aligned}
\text { Flow }_{i, t}=a_{0} & +b_{1} \times \text { Low }_{i, t-1}+b_{2} \times \text { Mid }_{i, t-1}+b_{3} \times \text { High }_{i, t-1} \\
& +b_{4} \times \text { Low }_{i, t-1} \times \text { MarketDummy }_{t-1}+b_{5} \times \text { Mid }_{i, t-1} \times \text { MarketDummy }_{t-1} \\
& +b_{6} \times \text { High }_{i, t-1} \times \text { MarketDummy }_{t-1}+\text { Controls }_{t-1}+\varepsilon_{i, t}
\end{aligned}
$$

One of the following dummy variables is used to replace the MarketDummy variable in Equation (4): up, volatile, up-quiet, up-volatile, down-quiet, and down-volatile. For a given month t, the dummy variable up takes value of 1 if the equity market return in excess of 1-month Treasury-bill return is positive, and 0 otherwise. The dummy variable volatile takes value of 1 if the average daily equity market return volatility in month $\mathrm{t}$ is more than average volatility of the whole sample period, and 0 otherwise. ${ }^{19}$ Compared to the up and volatile dummy variables that describe general market movements and volatility, the latter four dummy variables capture market conditions in a much greater scope. For instance, the dummy variable up-quiet is defined as taking value of 1 if the equity market in month $t$ is both up and quiet (or when up=1 and volatile=0), and 0 otherwise. The estimated coefficients on the interaction terms $\left(b_{4}, b_{5}, b_{6}\right)$ thus capture the impact of a specific market condition on the flowperformance relationship when that market condition is present (that is, MarketDummy=1), while the estimated coefficients on Low, Mid, and High $\left(b_{1}, b_{2}, b_{3}\right)$ represent the slope of the flow-performance

\footnotetext{
${ }^{18}$ We have also used the original methodology developed by Sirri and Tufano (1998), and obtained similar results using the following fractional performance rank definitions of Low, Mid, and High: $\operatorname{Low}_{t}=\operatorname{Min}\left(0.2, \operatorname{Rank}_{\mathrm{t}}\right)$; $\operatorname{Mid}_{\mathrm{t}}=\operatorname{Min}\left(0.6, \operatorname{Rank}_{\mathrm{t}}-\mathrm{Low}_{\mathrm{t}}\right) ;$ and $\operatorname{High}_{\mathrm{t}}=\mathrm{Rank}_{\mathrm{t}}-\mathrm{Low}_{\mathrm{t}}-\operatorname{Mid}_{\mathrm{t}}$.

${ }^{19}$ We have tried alternative definitions of up and volatile dummies, and results remain qualitatively the same.
} 
relationship over their range of sensitivity when a specific market condition is not present (that is, MarketDummy=0).

We also include multiple non-performance related fund characteristics as control variables in Equation (4). The monthly dummies and style dummies are also included in the regression to control for monthly effect and different fund investment styles respectively. Empirical results estimated from Equation (4) are reported in Table 5, where Panel A reports results associated with past raw returns, and Panel B with risk-adjusted returns (8-factor alphas). Among seven models reported, Model 1 (M1) serves as the baseline regression model that groups all market conditions together, while Models M2-M7 report the regression results that correspond to individual market conditions described by the six market dummy variables defined above respectively.

\section{A. Flow and Past Performance}

The baseline piecewise regression model M1 in Table 5 suggests a concave relationship between hedge fund flow and past performance. Hedge fund investors as a group are positively responding to fund past performance, although the level of responsiveness is different at different levels of past performance. This effect is captured by coefficient estimates of different performance rank groups. In particular, estimated coefficients (in \%) of (Low, Mid, High) are $(0.026,0.045,0.005)$ in the case of raw returns, and $(0.022$, $0.023,0.005)$ in the case of risk-adjusted returns, respectively. Except the group with top risk-adjusted returns, all other groups have statistically significant coefficients at $1 \%$ level. This is consistent with Goetzmann, Ingersoll, and Ross (2003) who find a concave flow-performance relation during the 19901995 period and Ding et al.(2009) who find a concave relation between fund flow and fund performance when share restrictions are considered.

Consistent with most existing literature, we find multiple fund characteristics included in the model as controls have a significant impact on future fund flows. Investors tend to favor funds with higher management fees, larger amount of fund flows during the past year, proposing high-water mark, and managers' personal capital invested in the fund. These characteristics are generally perceived as positive signals of good managerial skills and better manager incentives, and therefore attracting more flows into the fund. On the other hand, fund size has a significant negative impact on fund flows. This may indicate investors' general concern on the diminishing returns to scale in the hedge fund industry, which is in line with the observation by Berk and Green (2004) in the mutual fund industry. In addition, new fund flows tend to shy away from funds with high past performance volatility and with minimum investment amount requirement. Furthermore, U.S.-based funds and proposing lockup period seem to have a marginal 
positive effect on the flows, while investors are not significantly affected by the fund age and its leverage status.

Table 5: Impact of Different Market Conditions on Flow Sensitivity to Past Performance

The table reports pooled piecewise OLS regression results of fund flow in a given month on lagged fund performance over the past 12 months, their interactions with market condition dummies and lagged fund characteristics. Fund performance is measured as either average raw returns (Panel A) or risk-adjusted returns using eight-factor model (Panel B) over the past 12 months. To estimate piecewise regressions, we assign monthly fractional ranks from 0 to 1 based on their past performance. The bottom group (Low) is defined as Min(Rank,1/3); the middle group (Mid) is defined as Min(1/3, rank-Low) and high group is defined as (rank-Low-Mid). For a given month, the dummy variable Up takes value of 1 if the equity market return in excess of one-month Treasury-bill return is positive, and 0 otherwise. The dummy Volatile (Vol) takes value of 1 for the month when the average daily equity market return volatility is more than average volatility of the whole sample period, and 0 otherwise. The lagged fund characteristics include performance volatility over the past 12 months (Volatility), management fees, natural logarithm of assets under management (Fund size), natural logarithm of (1+age) (Fund age), fund flows over the past 12 months (Lagged flow), lockup period (Lockup), minimum investment, incentive fees, off shore dummy (Offshore), fund manager's personal investment in the funds (Personal capital), high-water mark dummy (Watermarked) and leverage dummy (Leveraged). Style dummies are also included to control for hedge funds' investment styles. $t$-statistics reported along with the coefficients are adjusted for heteroskedasticity and autocorrelations. Adjusted $\mathrm{R}^{2} \mathrm{~s}$ are in percent. The sample period is from 1994 to 2009.

\begin{tabular}{|c|c|c|c|c|c|c|c|c|c|c|c|c|c|c|}
\hline & \multicolumn{14}{|c|}{ Panel A: Raw Returns ass Performance Measure } \\
\hline & \multicolumn{2}{|c|}{ M1 } & \multicolumn{2}{|c|}{ M2 } & \multicolumn{2}{|c|}{ M3 } & \multicolumn{2}{|c|}{ M4 } & \multicolumn{2}{|c|}{ M5 } & \multicolumn{2}{|c|}{ M6 } & \multicolumn{2}{|c|}{ M7 } \\
\hline & Coef. & $t$-stat & Coef. & $t$-stat & Coef. & $t$-stat & Coef. & $t$-stat & Coef. & $t$-stat & Coef. & $t$-stat & Coef. & $t$-stat \\
\hline Low & 0.026 & 7.81 & 0.047 & 11.27 & 0.032 & 9.38 & 0.021 & 5.26 & 0.037 & 10.86 & 0.019 & 4.59 & 0.019 & 5.69 \\
\hline Mid & 0.045 & 21.20 & 0.043 & 15.32 & 0.043 & 18.00 & 0.047 & 18.63 & 0.043 & 19.27 & 0.044 & 16.41 & 0.045 & 20.35 \\
\hline High & 0.005 & 4.87 & 0.009 & 5.93 & 0.007 & 5.49 & 0.005 & 4.16 & 0.007 & 6.11 & 0.003 & 2.22 & 0.005 & 4.02 \\
\hline UpxLow & & & -0.045 & -8.29 & & & & & & & & & & \\
\hline UpxMid & & & 0.004 & 0.94 & & & & & & & & & & \\
\hline UpxHigh & & & -0.007 & -3.54 & & & & & & & & & & \\
\hline VolxLow & & & & & -0.034 & -9.58 & & & & & & & & \\
\hline VolxMid & & & & & 0.008 & 1.65 & & & & & & & & \\
\hline VolxHigh & & & & & -0.006 & -2.32 & & & & & & & & \\
\hline Up-quietxLow & & & & & & & 0.014 & 2.10 & & & & & & \\
\hline Up-quietxMid & & & & & & & -0.008 & -1.84 & & & & & & \\
\hline Up-quietxHigh & & & & & & & -0.001 & -0.29 & & & & & & \\
\hline Up-volxLow & & & & & & & & & -0.091 & -12.55 & & & & \\
\hline Up-volxMid & & & & & & & & & 0.015 & 2.58 & & & & \\
\hline Up-volxHigh & & & & & & & & & -0.012 & -3.83 & & & & \\
\hline Down-quiet & & & & & & & & & & & & & & \\
\hline xLow & & & & & & & & & & & 0.015 & 2.36 & & \\
\hline Down-quiet & & & & & & & & & & & & & & \\
\hline xMid & & & & & & & & & & & 0.001 & 0.17 & & \\
\hline Down-quiet & & & & & & & & & & & & & & \\
\hline xHigh & & & & & & & & & & & 0.005 & 2.42 & & \\
\hline Down-vol & & & & & & & & & & & & & & \\
\hline xLow & & & & & & & & & & & & & 0.064 & 8.30 \\
\hline Down-vol & & & & & & & & & & & & & & \\
\hline xMid & & & & & & & & & & & & & -0.007 & -1.18 \\
\hline $\begin{array}{l}\text { Down-vol } \\
\text { xHigh }\end{array}$ & & & & & & & & & & & & & 0.004 & 1.18 \\
\hline Volatility(\%) & -0.059 & -7.02 & -0.057 & -6.88 & -0.075 & -9.21 & -0.059 & -7.07 & -0.064 & -7.71 & -0.059 & -7.11 & -0.053 & -6.37 \\
\hline Mgmt. Fees & 0.017 & 4.10 & 0.017 & 4.12 & 0.013 & 3.06 & 0.017 & 4.11 & 0.018 & 4.29 & 0.017 & 4.13 & 0.017 & 4.07 \\
\hline Fund Size(\%) & -0.189 & -12.59 & -0.188 & -12.52 & -0.209 & -13.75 & -0.19 & -12.60 & -0.189 & -12.62 & -0.189 & -12.57 & -0.189 & -12.55 \\
\hline Fund Age(\%) & 0.016 & 0.28 & 0.016 & 0.28 & -0.159 & -2.78 & 0.017 & 0.29 & 0.02 & 0.35 & 0.016 & 0.28 & 0.016 & 0.28 \\
\hline Lagged Flow & 0.489 & 54.40 & 0.490 & 54.53 & 0.515 & 57.70 & 0.489 & 54.38 & 0.489 & 54.48 & 0.489 & 54.39 & 0.491 & 54.64 \\
\hline Lockup & 0.002 & 1.94 & 0.002 & 1.90 & 0.001 & 1.04 & 0.002 & 1.94 & 0.002 & 1.90 & 0.002 & 1.92 & 0.002 & 1.98 \\
\hline $\begin{array}{l}\text { Min. Investment } \\
\text { Incentive }\end{array}$ & -0.006 & -2.24 & -0.006 & -2.18 & -0.007 & -2.64 & -0.006 & -2.24 & -0.005 & -2.05 & -0.006 & -2.21 & -0.006 & -2.26 \\
\hline Fees(\%) & -0.020 & -0.37 & -0.019 & -0.36 & -0.034 & -0.62 & -0.019 & -0.36 & -0.015 & -0.29 & -0.019 & -0.35 & -0.023 & -0.42 \\
\hline OffShore(\%) & -0.074 & -1.46 & -0.073 & -1.44 & -0.138 & -2.69 & -0.074 & -1.46 & -0.074 & -1.48 & -0.075 & -1.49 & -0.072 & -1.42 \\
\hline $\begin{array}{l}\text { Personal } \\
\text { capital(\%) }\end{array}$ & 0.128 & 2.73 & 0.129 & 2.76 & 0.209 & 4.45 & 0.129 & 2.74 & 0.126 & 2.69 & 0.128 & 2.73 & 0.13 & 2.77 \\
\hline Watermarked(\%) & 0.178 & 3.32 & 0.176 & 3.27 & -0.005 & -0.09 & 0.179 & 3.34 & 0.181 & 3.37 & 0.178 & 3.31 & 0.177 & 3.31 \\
\hline Leveraged(\%) & 0.018 & 0.37 & 0.019 & 0.37 & 0.034 & 0.67 & 0.018 & 0.36 & 0.018 & 0.35 & 0.018 & 0.37 & 0.018 & 0.35 \\
\hline Adjusted $\mathrm{R}^{2}$ & 13.84 & & 14.01 & & 11.21 & & 13.85 & & 14.19 & & 13.86 & & 14.01 & \\
\hline
\end{tabular}


Table 5 - Continued: Impact of Different Market Conditions on Flow Sensitivity to Past Performance

\begin{tabular}{|c|c|c|c|c|c|c|c|c|c|c|c|c|c|c|}
\hline & \multicolumn{14}{|c|}{ " Panel B: Risk Adjusted Returns ass Performance Measure } \\
\hline & \multicolumn{2}{|c|}{ M1 } & \multicolumn{2}{|c|}{ M2 } & \multicolumn{2}{|c|}{ M3 } & \multicolumn{2}{|c|}{ M4 } & \multicolumn{2}{|c|}{ M5 } & \multicolumn{2}{|c|}{ M6 } & \multicolumn{2}{|c|}{ M7 } \\
\hline & Coef. & $t$-stat & Coef. & $t$-stat & Coef. & $t$-stat & Coef. & $t$-stat & Coef. & $t$-stat & Coef. & $t$-stat & Coef. & $t$-stat \\
\hline Low & 0.022 & 6.71 & 0.043 & 10.09 & 0.026 & 6.90 & 0.021 & 5.20 & 0.031 & 9.08 & 0.018 & 4.27 & 0.016 & 4.60 \\
\hline Mid & 0.023 & 9.21 & 0.021 & 6.00 & 0.022 & 7.57 & 0.025 & 8.08 & 0.022 & 7.91 & 0.023 & 6.99 & 0.024 & 9.09 \\
\hline High & 0.005 & 1.51 & 0.010 & 2.27 & 0.011 & 2.79 & 0.004 & 0.96 & 0.010 & 2.83 & 0.001 & 0.17 & 0.004 & 1.11 \\
\hline UpxLow & & & -0.043 & -7.74 & & & & & & & & & & \\
\hline UpxMid & & & 0.006 & 1.13 & & & & & & & & & & \\
\hline UpxHigh & & & -0.011 & -1.76 & & & & & & & & & & \\
\hline VolxLow & & & & & -0.017 & -2.27 & & & & & & & & \\
\hline VolxMid & & & & & 0.006 & 1.06 & & & & & & & & \\
\hline VolxHigh & & & & & -0.019 & -2.69 & & & & & & & & \\
\hline Up-quietxLow & & & & & & & 0.004 & 0.55 & & & & & & \\
\hline Up-quietxMid & & & & & & & -0.005 & -1.00 & & & & & & \\
\hline Up-quietxHigh & & & & & & & 0.003 & 0.53 & & & & & & \\
\hline Up-volxLow & & & & & & & & & -0.076 & -10.23 & & & & \\
\hline Up-volxMid & & & & & & & & & 0.016 & 2.16 & & & & \\
\hline Up-volxHigh & & & & & & & & & -0.028 & -3.12 & & & & \\
\hline Down-quiet & & & & & & & & & & & & & & \\
\hline xLow & & & & & & & & & & & 0.009 & 1.37 & & \\
\hline Down-quiet & & & & & & & & & & & & & & \\
\hline xMid & & & & & & & & & & & 0.000 & 0.05 & & \\
\hline $\begin{array}{l}\text { Down-quiet } \\
\text { xHigh }\end{array}$ & & & & & & & & & & & 0.011 & 1.77 & & \\
\hline $\begin{array}{l}\text { Down-vol } \\
\text { xLow }\end{array}$ & & & & & & & & & & & & & 0.069 & 8.81 \\
\hline $\begin{array}{l}\text { Down-vol } \\
\text { xMid }\end{array}$ & & & & & & & & & & & & & -0.009 & -1.14 \\
\hline $\begin{array}{l}\text { Down-vol } \\
\text { xHigh }\end{array}$ & & & & & & & & & & & & & -0.002 & -0.16 \\
\hline Volatility(\%) & -0.016 & -2.57 & -0.015 & -2.40 & -0.020 & -3.17 & -0.016 & -2.55 & -0.022 & -3.49 & -0.017 & -2.79 & -0.010 & -1.53 \\
\hline Mgmt. Fees & 0.020 & 4.78 & 0.020 & 4.79 & 0.020 & 4.86 & 0.020 & 4.78 & 0.021 & 4.99 & 0.020 & 4.81 & 0.019 & 4.66 \\
\hline Fund Size(\%) & -0.171 & -11.39 & -0.170 & -11.33 & -0.172 & -11.44 & -0.171 & -11.39 & -0.172 & -11.42 & -0.171 & -11.39 & -0.170 & -11.30 \\
\hline Fund Age(\%) & 0.038 & 0.64 & 0.036 & 0.61 & 0.037 & 0.63 & 0.038 & 0.64 & 0.036 & 0.61 & 0.038 & 0.64 & 0.036 & 0.61 \\
\hline Lagged Flow & 0.526 & 58.72 & 0.527 & 58.85 & 0.526 & 58.68 & 0.526 & 58.72 & 0.526 & 58.86 & 0.526 & 58.72 & 0.527 & 58.92 \\
\hline Lockup & 0.003 & 2.43 & 0.003 & 2.42 & 0.003 & 2.43 & 0.003 & 2.43 & 0.003 & 2.40 & 0.003 & 2.42 & 0.003 & 2.46 \\
\hline $\begin{array}{l}\text { Min. Investment } \\
\text { Incentive }\end{array}$ & -0.004 & -1.66 & -0.004 & -1.65 & -0.004 & -1.62 & -0.004 & -1.67 & -0.004 & -1.56 & -0.004 & -1.65 & -0.004 & -1.68 \\
\hline Fees(\%) & -0.012 & -0.23 & -0.013 & -0.23 & -0.011 & -0.21 & -0.012 & -0.23 & -0.010 & -0.18 & -0.012 & -0.22 & -0.016 & -0.30 \\
\hline OffShore(\%) & -0.100 & -1.97 & -0.101 & -1.98 & -0.103 & -2.02 & -0.100 & -1.97 & -0.104 & -2.04 & -0.101 & -1.99 & -0.099 & -1.95 \\
\hline Personal & & & & & & & & & & & & & & \\
\hline capital(\%) & 0.145 & 3.07 & 0.147 & 3.11 & 0.144 & 3.05 & 0.145 & 3.07 & 0.145 & 3.07 & 0.145 & 3.06 & 0.146 & 3.10 \\
\hline Watermarked(\%) & 0.209 & 3.87 & 0.207 & 3.83 & 0.210 & 3.88 & 0.209 & 3.87 & 0.207 & 3.82 & 0.209 & 3.86 & 0.210 & 3.88 \\
\hline Leveraged(\%) & -0.016 & -0.31 & -0.016 & -0.31 & -0.017 & -0.33 & -0.016 & -0.32 & -0.016 & -0.32 & -0.016 & -0.31 & -0.014 & -0.28 \\
\hline Adjusted $\mathrm{R}^{2}$ & 12.66 & & 12.82 & & 12.68 & & 12.66 & & 12.95 & & 12.68 & & 12.84 & \\
\hline
\end{tabular}

\section{B. Flow Sensitivities under Different Market Conditions}

M2 and M3 of Table 5 investigate how a general market condition such as up/down or quiet/volatile affects the fund flow-performance sensitivities. Results indicate a strong and asymmetric impact of different markets on hedge fund flow-performance sensitivities.

M2 tests whether up markets have a significantly different impact on flow sensitivities to past performance from down markets. Market dummy up is thus introduced into the model and interact with different performance ranks to capture the effect. We find that among three estimated coefficients of interaction terms, up $\times$ Low and up $\times$ High are significantly negative in both panels, indicating significantly reduced flow-sensitivities during the up markets for bottom- and top-tier performing groups. In particular, compared to down markets (up dummy=0), up markets (up dummy=1) show that flow 
sensitivities to bottom performance are significantly reduced by about $96 \%$, from 0.047 to 0.002 in the case of raw returns (and by about $100 \%$, from 0.043 to 0 in the case of risk-adjusted returns). Similarly, average flow sensitivities to top performance during up markets drop by about 78\%, from 0.009 to 0.002 when measured by raw returns (or by $100 \%$ from 0.010 to -0.001 when measured by risk-adjusted returns). As a result, estimated coefficients (in \%) of (Low, Mid, High) change from (0.047, 0.043, 0.009) in down markets (up dummy $=0)$ to $(0.002,0.047,0.002)$ in up markets when fund performance is measured by raw returns, or from $(0.043,0.021,0.010)$ in down markets to $(0.000,0.027,-0.001)$ in up markets when measured by alphas. In other words, a typical concave flow-performance relationship is only observed during down markets, while flows turn completely insensitive to past losers and winners during up markets for hedge funds in the high and low performance ranges. At the same time, up and down market conditions do not affect flow sensitivities to funds with medium performance, which stay significantly positive all times.

In M3, the market dummy volatile replaces the up dummy in M2 and interacts with performance ranks to test whether volatile and quiet market conditions affect the flow-performance sensitivities differently. An asymmetric flow-performance relationship is again observed when market is divided into quiet and volatile conditions. Similar to up/down markets, flow-performance sensitivities are not much affected by specific market conditions for medium performance funds. Funds in both bottom and top performing groups, however, have much flatter flow sensitivities during volatile markets (volatile dummy=1), while quiet markets (volatile dummy=0) are associated with a generally concave flowperformance relationship. In particular, for (Low, Mid, High) performance ranges, flow sensitivities are significantly altered from $(0.032,0.043,0.007)$ in quiet markets to $(-0.002,0.051,0.001)$ in volatile markets when measured by raw returns, and from $(0.026,0.022,0.011)$ in quiet markets to $(0.009,0.028$, -0.008) in volatile markets when measured by risk-adjusted returns.

Results from M2 and M3 tend to suggest that the general concave flow-performance relationship observed in the baseline model (M1) is largely driven by either down or quiet market conditions. More importantly, our findings reflect significant changes of investor sentiment toward hedge funds with extreme performance under different market conditions. During volatile markets, it seems intuitive that hedge fund investors become more cautious and refrain from their investment activities when there is significant uncertainty in predicting the future market movements, hence reducing the sensitivities to funds with extreme performance. On the other hand, it is interesting to note that during down markets hedge fund investors appear to be more sensitive to past fund performance than they do during up markets. While both volatile and down markets are usually considered undesirable market conditions, our evidence suggests very different patterns of flow sensitivity in the two markets. In light of this observation, we 
further break down the market conditions and investigate the impact of a specific market condition on flow-performance pattern in a greater detail.

Results from M4-M7 confirm a generally strong but asymmetric impact of a particular market condition on flow sensitivities toward funds with extreme performance. Both performance measures show similar patterns, with slightly weaker statistical significance in the case of risk-adjusted returns as the proxy for fund performance. Except up-volatile markets that significantly affect flow sensitivities to mid-range performance funds, all other market conditions usually have strong impacts, if any, on low and high performance groups only. More specifically, up-volatile markets are associated with significantly reduced flow sensitivities for both bottom and top performance groups, while all other markets are with increased sensitivities. As a result, net flow sensitivities to low performance are 0.035, $-0.054,0.034$, and 0.083 when measured by raw returns (or $0.025,-0.045,0.027$, and 0.085 when measured by risk-adjusted returns) for up-quiet, up-volatile, down-quiet, and down-volatile markets separately. The net flow sensitivities to high performance funds are 0.004, -0.005, 0.008, and 0.009 (or 0.007, -0.018, 0.012, and 0.002 when measured by risk-adjusted returns) for up-quiet, up-volatile, down-quiet, and down-volatile markets respectively.

For low performance fund groups, it is worthwhile to note that among the four market conditions, up-volatile markets witness the least flow sensitivity to fund performance with coefficient estimate of the interaction term Up-volatile $\times$ Low of -0.091 (t-stat=-12.55) in the case of raw returns, and -0.076 (tstat $=-10.23$ ) in the case of 8 -factor alphas. This suggests an overall negative flow sensitivity to the low performance funds during up-volatile markets (-0.054 in the raw return case, and -0.045 in the riskadjusted return case), indicating that past losers even attract more new funds than past winners. On the other hand, the flow-performance sensitivity is most significant in down-volatile markets, indicating that investors invest more past winners in the low performing fund group. For high performance fund groups, however, flow sensitivities are most positively affected during down-quiet markets and most negatively affected during up-volatile markets. When fund performance is measured by risk-adjusted returns, the “chasing past winners” behavior of fund investors is strongest during down-quiet markets, with estimated coefficient of the Down-quiet $\times$ High of 0.011 (t-stat $=1.77$ ), resulting a net flow sensitivity to high performance funds of 0.012. The most negative impact toward flow-performance relationship is detected during up-volatile markets, with coefficient of interaction term of $-0.028(t-s t a t=-3.12)$, resulting a net flow sensitivity of -0.018 . On the other hand, up-quiet and down-volatile markets seem to have little influence on the flow sensitivities toward past winners. 
Our overall results indicate changes of investment behaviors from investors between up and down markets, and between quiet and volatile markets are mainly driven by the up-volatile and down-volatile market conditions. This observation is clearer when using risk-adjusted returns as the performance measure. If markets are quiet, hedge fund investors have strong incentive to chase fund performance and flow-performance relation in general remains similar between up and down markets. Therefore, when markets are relatively calm and predictable, market direction has almost no impact on the investment behaviors of hedge fund investors. However, investors become less sensitive to past performance during up-volatile markets, but become highly sensitive to past performance during down-volatile markets. Thus, both upside and downside volatilities matter for hedge fund investors. Combining results from summary statistics, we find that hedge fund investors not only reduce investment during both up- and down-volatile markets but also demonstrate different behaviors under these two markets.

\section{Robustness Check}

We also apply stricter rules to adjust sample funds to mitigate issues related to the times in which investment decisions are taken with the market conditions prevailing at those times, the match of the frequency and length of the hedge fund investing process, and a short sample for up-volatile times. It is arguable that dealing frequencies and share restrictions may affect our findings. Moreover, there is a relatively shorter period of 17 months in the up-volatile market. In this study, we assume that hedge fund investors are smart. Thus, they have already incorporated all these restrictions into the consideration when they make their investment decisions. As Ferson and Kim (2012) document, investors may face some frictions when they make their investment decisions even though fund flows can predict future economic conditions. It is of interest to explore how these frictions could alter our findings. Thus, we repeat our tests using a refined sample that is supposed to have fewer problems with these issues.

Our new sample includes hedge funds with (1) both redemption and subscription frequencies are one month or below (daily, monthly, fortnightly, semi-monthly and weekly); (2) the notice period is between none and one month (30 days); (3) no other share restrictions are applied. We also divide months into halves or terciles according to their monthly market volatility and define the top half or tercile as volatile markets. The numbers of months for up-volatile and down-volatile markets are now 43 and 45, respectively, when grouping months in halves, and 32 and 26, respectively, when using the months in the top tercile as volatile markets. ${ }^{20}$

\footnotetext{
${ }^{20}$ The results are not sensitive to grouping methods for months. The complete tables are available upon request.
} 
Results are generally similar to the ones in Table 5. Hedge fund investors have different behaviors between up-volatile and down-volatile markets. They also demonstrate different investment strategies between quiet and volatile markets although the change of investment behaviors is marginal significant ( $\mathrm{t}$-stat $=$-1.78). However, we notice that there are some changes. The flow-performance relation in the Model 1 for the best performing funds becomes significant while the shape is still concave. We further find that the changes of investment behaviors mainly occur in the fund group with the worst performance - hedge fund investors become insensitive to fund performance in the up-volatile markets and are more sensitive to fund performance in the down-volatile markets. When comparing new results with Table 5, restrictions with hedge fund investing seem to strengthen the behavior patterns in Table 5. Although share restrictions may affect the investment decisions, assessing the overall net impact of share restrictions on investment behaviors is beyond the scope of this study. Our purpose in this paper is to show that upside and downside volatilities both affect investment behaviors and to explore whether up- and down-volatile markets have different impacts on the investors' investment strategies.

\section{Smart Money under Different Market Conditions}

Given the asymmetric flow-performance sensitivities observed under different market conditions from previous subsection, it is of interest to examine whether hedge fund investors have an ability to predict future fund performance and how this ability varies with market conditions. If hedge fund investors have the ability to predict future fund performance, their change of investment behaviors found in the previous section should offer some meaningful implications. Therefore, it is worthwhile to investigate whether fund investors can benefit from doing so, or whether the money is "smart" in the hedge fund industry.

We follow the standard approach in the literature to test the smart money effect. For each given month t, we first sort all funds according to their past 3-month flows into quintiles, and denote them from the highest (Group 1) to the lowest (Group 5). We then track the average value-weighted portfolio returns over 3-month and 12-month period within each flow quintile respectively, and test the statistical significance for returns. The return spreads between the highest and lowest flow quintile portfolios are also examined. The tests are performed for the whole sample period, four market conditions (up, down, quiet, and volatile), and the further market condition breakdowns (up-quiet, up-volatile, down-quiet, and down-volatile markets). Table 6 reports the test results, with Panel A reporting the flow performance for a 3-month period, and Panel B for a 12-month period. For brevity, the performance measures reported in both panels are the augmented 8-factor alphas, although very similar results are obtained when using buyand-hold raw returns. ${ }^{21}$

${ }^{21}$ Results using buy-and-hold returns are available upon request. 
Table 6: Smart Money Performance of Hedge Fund Flows

The table reports average risk-adjusted returns $(\alpha)$ on all hedge funds within each flow quintile for a period of three months (Panel A) or 12 months (Panel B), and performance difference between top and bottom quintiles (H-L). At the beginning of each month, hedge funds are sorted into five fund flow quintiles, according to the past three-month fund net flow. Quintile 1 (High) consists of hedge funds with the highest fund flow. All months are further divided into subperiods according to the market conditions. Market conditions include up, down, quiet, volatile markets and their combinations. See Table 2 for definitions of various market conditions. Risk-adjusted returns are evaluated by using the augmented eight-factor model described in Table 4 . The sample period is from 1994 to 2009.

\begin{tabular}{|c|c|c|c|c|c|c|c|c|}
\hline \multirow[t]{2}{*}{ Flow Rank } & $\alpha$ & tat & $\alpha$ & $t$-stat & $\alpha$ & $t$-stat & $\alpha$ & $t$-stat \\
\hline & \multicolumn{8}{|c|}{ Panel A: Performance in Three Months } \\
\hline & \multicolumn{2}{|c|}{ Overall } & & & & & & \\
\hline 1-High & 0.588 & 7.46 & & & & & & \\
\hline 2 & 0.499 & 6.23 & & & & & & \\
\hline 3 & 0.505 & 6.08 & & & & & & \\
\hline 4 & 0.462 & 5.39 & & & & & & \\
\hline 5-Low & 0.366 & 4.45 & & & & & & \\
\hline \multirow[t]{2}{*}{$\mathrm{H}-\mathrm{L}$} & 0.222 & 3.73 & & & & & & \\
\hline & \multicolumn{2}{|c|}{ Up } & \multicolumn{2}{|c|}{ Down } & \multicolumn{2}{|c|}{ Quiet } & \multicolumn{2}{|c|}{ Volatile } \\
\hline 1-High & 0.628 & 7.59 & 0.575 & 7.07 & 0.589 & 7.33 & 0.758 & 4.36 \\
\hline 2 & 0.537 & 6.37 & 0.508 & 6.02 & 0.510 & 6.00 & 0.624 & 3.50 \\
\hline 3 & 0.555 & 6.32 & 0.487 & 5.71 & 0.521 & 5.85 & 0.417 & 2.83 \\
\hline 4 & 0.483 & 5.29 & 0.434 & 4.93 & 0.463 & 5.16 & 0.516 & 3.09 \\
\hline 5-Low & 0.400 & 4.47 & 0.327 & 3.92 & 0.347 & 4.06 & 0.591 & 3.53 \\
\hline \multirow[t]{2}{*}{ H-L } & 0.228 & 3.44 & 0.248 & 3.79 & 0.242 & 3.71 & 0.167 & 1.30 \\
\hline & \multicolumn{2}{|c|}{ Up-quiet } & \multicolumn{2}{|c|}{ Up-volatile } & \multicolumn{2}{|c|}{ Down-quiet } & \multicolumn{2}{|c|}{ Down-volatile } \\
\hline 1-High & 0.572 & 6.53 & 0.760 & 3.77 & 0.624 & 7.51 & 0.637 & 2.44 \\
\hline 2 & 0.495 & 5.62 & 0.567 & 2.88 & 0.525 & 6.00 & 0.570 & 2.24 \\
\hline 3 & 0.548 & 5.76 & 0.327 & 2.03 & 0.541 & 5.84 & 0.318 & 1.38 \\
\hline 4 & 0.442 & 4.72 & 0.473 & 2.47 & 0.450 & 4.84 & 0.438 & 1.95 \\
\hline 5-Low & 0.317 & 3.61 & 0.465 & 2.32 & 0.339 & 3.85 & 0.657 & 2.99 \\
\hline \multirow[t]{3}{*}{$\mathrm{H}-\mathrm{L}$} & 0.255 & 3.53 & 0.295 & 1.97 & 0.285 & 4.10 & -0.019 & -0.09 \\
\hline & \multicolumn{8}{|c|}{ Panel B: Performance in Twelve Months } \\
\hline & \multicolumn{2}{|c|}{ Overall } & & & & & & \\
\hline 1-High & 0.558 & 7.35 & & & & & & \\
\hline 2 & 0.470 & 5.96 & & & & & & \\
\hline 3 & 0.477 & 6.51 & & & & & & \\
\hline 4 & 0.442 & 5.57 & & & & & & \\
\hline 5-Low & 0.399 & 4.98 & & & & & & \\
\hline \multirow[t]{2}{*}{$\mathrm{H}-\mathrm{L}$} & 0.158 & 3.13 & & & & & & \\
\hline & \multicolumn{2}{|c|}{ Up } & \multicolumn{2}{|c|}{ Down } & \multicolumn{2}{|c|}{ Quiet } & \multicolumn{2}{|c|}{ Volatile } \\
\hline 1-High & 0.586 & 7.65 & 0.557 & 7.29 & 0.572 & 7.48 & 0.576 & 4.69 \\
\hline 2 & 0.479 & 5.90 & 0.473 & 5.94 & 0.470 & 5.96 & 0.400 & 3.11 \\
\hline 3 & 0.478 & 6.56 & 0.476 & 6.36 & 0.479 & 6.53 & 0.386 & 3.68 \\
\hline 4 & 0.437 & 5.57 & 0.433 & 5.29 & 0.425 & 5.33 & 0.430 & 3.85 \\
\hline 5-Low & 0.422 & 5.16 & 0.396 & 4.91 & 0.385 & 4.77 & 0.481 & 4.08 \\
\hline \multirow[t]{2}{*}{$\mathrm{H}-\mathrm{L}$} & 0.164 & 3.19 & 0.161 & 3.02 & 0.187 & 3.59 & 0.095 & 1.14 \\
\hline & Up- & & Up-v & atile & Down & uiet & Down- & latile \\
\hline 1-High & 0.573 & 7.15 & 0.523 & 4.08 & 0.575 & 7.67 & 0.522 & 3.54 \\
\hline 2 & 0.477 & 5.83 & 0.429 & 2.92 & 0.478 & 6.07 & 0.377 & 2.61 \\
\hline 3 & 0.475 & 6.47 & 0.434 & 3.53 & 0.487 & 6.5 & 0.325 & 2.81 \\
\hline 4 & 0.422 & 5.41 & 0.397 & 2.98 & 0.421 & 5.08 & 0.415 & 3.45 \\
\hline 5-Low & 0.407 & 4.96 & 0.455 & 3.32 & 0.384 & 4.71 & 0.466 & 3.76 \\
\hline H-L & 0.166 & 3.09 & 0.069 & 0.78 & 0.191 & 3.57 & 0.056 & 0.53 \\
\hline
\end{tabular}

Panel A indicates the existence of a strong smart money effect among hedge fund investors over a 3-month period. Using the whole sample period (overall), we find a generally decreasing flow performance along with the descending flow quintile order, with the highest flow quintile significantly outperforming the lowest flow quintile. When market conditions are divided into either up/down or 
quiet/volatile cases, the performance pattern of each flow quintile in up, down, and quiet markets is very similar to the overall pattern. It is interesting, however, to note that the smart money effect is much weaker or even disappearing during volatile markets with a typical U-shaped pattern in performance. That is, fund flow performance is first decreasing and then increasing with the flow quintile rank after medium group, causing a much smaller (and insignificant) performance gap between the top and bottom flow quintiles.

When market conditions are further divided into combinations of up/down and quite/volatile markets, it is worth noting that down-quiet markets witness the strongest smart money effect over the 3-month window ( $0.29 \%$ per month or 3.42 per annum, with t-stat of 4.10 at the $1 \%$ significance level). The Ushaped pattern of fund performance across flow quintiles during volatile markets is particularly magnified in down-volatile markets. The bottom flow quintile even slightly outperforms the top quintile, resulting in a negative but insignificant performance difference between two groups. The up-volatile markets present a similar but less extreme U-shaped pattern, resulting in a slightly weaker yet still statistically significant smart money effect (with top-bottom performance difference of $0.295 \%$ and $t$-stat $=1.97$ ). This observation suggests that during volatile markets, especially down-volatile markets, future fund performance becomes more uncertain and harder to predict, thus introducing a lot of noise into investors' investment decisions. As a result, funds that experienced the highest level of flows do not necessarily outperform those with the lowest level of flows subsequently.

Panel B of Table 6 tracks flow performance over a longer period (12 months), and the smart money effect over the whole sample period is still strong and significant. Compared to the findings in Panel A, all flow quintiles except the bottom group have lower returns, and that performance of each quintile tends to converge. The bottom flow quintile has slightly improved performance, resulting in a narrowed but still significant difference between the top and bottom quintiles. The breakdowns of market conditions also show patterns very similar to their counterparts in Panel A, with smaller difference between the top and bottom flow quintiles. Again, the strongest smart money effect is detected in down-quiet markets $(0.19 \%$ per month or $2.29 \%$ per annum, with t-stat of 3.57 at the $1 \%$ significance level), and volatile markets still stand out as a special case with a unique U-shaped pattern of flow performance compared to other market conditions.

During turbulent market periods, funds with the highest flows perform better than those with the lowest flows over the 12-month horizon, but the difference is insignificant, indicating no smart money effect for new investments made. Such a pattern is further confirmed in both up-volatile and downvolatile markets, where the smart money effect completely disappears over the 12-month window. 
Instead, the bottom flow quintile generates higher returns than all the middle three quintiles in all volatile markets. Therefore, hedge fund flows cannot predict future fund performance when market is turbulent and volatile, while the observed smart money effect in general is largely driven by quiet market conditions where fund performance is more stable and predictable.

In summary, Table 6 suggests that various market conditions play a significant role in investors' investment decisions and affect subsequent performance of new fund flows asymmetrically. In particular, volatile markets have a much weaker or disappearing smart money effect compared to stable and quiet markets, while up and down markets have very similar patterns of smart money effect, which is also comparable to the overall case. We further observe that - first, hedge fund investors have the best ability to predict future fund performance in down-quiet markets and have the worst ability in down-volatile markets; and second, investors have the second best ability in the up-quiet markets and the second worst ability in the up-volatile markets. Thus, upside volatility also reduces hedge fund investors' ability to pick outperforming funds. Since fund investors usually use fund past performance to judge fund managers' skill, it is interesting to examine whether past performance cannot be used to predict future fund performance during volatile markets as Busse (1999) suggests. If this is the case, we will find that fund

performance does not persist in volatile markets. In the next section, we continue to investigate performance persistence for hedge funds under various market conditions.

\section{Performance Persistence}

Given a smart money effect detected in the overall market but with a very different pattern during volatile markets, it is interesting to investigate whether this effect is associated with the fund performance persistence over the same windows. Performance persistence is well documented in the hedge fund literature. For example, Agarwal and Naik (2000) have documented maximum fund persistence at a quarterly horizon. Bares, Gibson, and Gyger (2003) also detect fund performance persistence over shortterm holding periods such as one to three months, but rapidly vanishes with longer holding periods. However, none of the studies have examined the performance persistence under a given market condition. In this section, we investigate whether fund performance persists under different market conditions, and if so, whether it contributes to the observed smart money effect in Table 6.

A pooled regression approach is employed to examine the hedge fund performance persistence. Namely, we use the following regression model to perform the analysis:

$$
\begin{aligned}
\alpha_{i, t+n}=a_{0} & +b_{1} \times \alpha_{i,(t-12, t-1)}+b_{2} \times \text { Flow }_{i,(t-12, t-1)}+b_{3} \times \text { MarketDummy }_{i} \times \alpha_{i,(t-12, t-1)} \\
& +b_{4} \times \text { MarketDummy }_{i} \times \text { Flow }_{i,(t-12, t-1)}+\text { Controls }_{(t-12, t-1)}+\varepsilon_{i, t}
\end{aligned}
$$


Here $\alpha_{\mathrm{i}, \mathrm{t}+\mathrm{n}}$ is fund i's performance over the subsequent $\mathrm{n}(\mathrm{n}=3$ or 12$)$ months. $\alpha_{\mathrm{i},(\mathrm{t}-12, \mathrm{t}-1)}$ is lagged fund performance during the past 12 months. Flow $\mathrm{i,t(t-12, \textrm {t } - 1 )}$ is the average monthly fund flow during the past year. For brevity, the fund performance is evaluated using the risk-adjusted return estimated from the augmented 8-factor model. ${ }^{22}$ To estimate the risk-adjusted return $\alpha$, factor loadings of the 8-factor model are first estimated using a 24-month window of $(\mathrm{t}-11, \mathrm{t}+12)$ for any given month $\mathrm{t}$. With parameter estimates, the one-month $\alpha$ is then calculated as the difference between the realized excess return and the expected return estimated from the model. Past fund performance $\left(\alpha_{\mathrm{i},(\mathrm{t}-12, \mathrm{t}-1)}\right)$ is measured as the average monthly risk-adjusted return from the 8-factor model over the past 12 months. Other lagged fund characteristics included in the model as control variables are volatility of fund performance, management fees, incentive fees, fund size, fund age, and dummy variables to control for the fund's lockup period proposition, minimum investment amount requirement, high-water mark protection, leverage, offshore operation, and investment of manager's personal capital in the fund. In addition, 12 style dummies are included to control for different investment styles.

Table 7 provides results for fund performance persistence tests, with Panel A reporting results for a 3month test, and Panel B for a 12-month test, separately. Similar to Table 5, Model 1 (M1) serves as the baseline regression model that groups all market conditions together without including any market dummy variables, while Models M2-M7 report regression results that correspond to individual market conditions respectively. The reported t-statistics are adjusted for the heteroskedasticity and autocorrelations. For brevity, we only report the coefficients on the main variables of interest.

As shown in M1, the baseline model that does not include any market dummies suggests a clear pattern of strong persistence in hedge fund performance over both three and twelve months - past fund performance has a significant positive impact on future performance over these two periods even after controlling for various hedge fund characteristics. Past fund flows, as one of control variables, however, has a significant negative impact on subsequent fund performance. Thus, net fund inflows disrupt fund mangers' ability to provide consistent fund performance and this negative effect can even outweigh the benefit of fund performance persistence.

M2 investigates whether up and down markets have a significant impact on fund performance persistence by interacting with the up market dummy on both past fund performance and lagged fund flows respectively. Both Panels report negative but insignificant coefficient estimates of interaction terms up $\times$ $\alpha_{(t-12, t-1)}$ and up $\times$ Flow $_{(t-12, t-1)}$. Results suggest a negligible additional impact of up or down market on fund

\footnotetext{
${ }^{22}$ We also use the raw returns as the fund performance measure, and results are qualitatively the same.
} 


\section{Table 7: Performance Persistence of Hedge Funds under Different Market Conditions}

The table reports the pooled OLS regression results of fund performance over the subsequent 3 months (Panel A) and 12 months (Panel B) on lagged 12-month fund performance and fund flow, their interactions with market condition dummies and lagged fund characteristics. Fund performance is measured as risk-adjusted returns (estimated abnormal return). To calculate the estimated risk-adjusted return, the parameters of the eight-factor model are estimated first using window of $(\mathrm{t}-11, \mathrm{t}+12)$. With the parameter estimates, the one-month abnormal return is calculated as the difference between real excess return and expected return from the model. Past fund performance $\left(\alpha_{(t-12, t-1)}\right)$ is measured as the average monthly risk-adjusted returns from the eight-factor model over the past 12 months. See Table 2 for detailed information of market conditions. In addition to lagged fund performance and flows, we also include the following lagged fund characteristics as control variables (not reported): fund performance volatility over the past 12 months, management fees, incentive fees, assets under management, fund age, and dummies that indicate the fund's lockup period proposition, minimum investment requirement, offshore operation, manager's personal investment in the fund, high-water mark protection, and whether the fund is leveraged. Style dummies are also included to control for hedge funds' investment styles. $t$-statistics are reported along with the coefficients after adjusted for heteroskedasticity and autocorrelations. Adjusted $\mathrm{R}^{2} \mathrm{~s}$ are in percent. The sample period is from 1994 to 2009.

\begin{tabular}{|c|c|c|c|c|c|c|c|c|c|c|c|c|c|c|}
\hline & \multicolumn{2}{|c|}{ M1 } & \multicolumn{2}{|c|}{ M2 } & \multicolumn{2}{|c|}{ M3 } & \multicolumn{2}{|c|}{$\mathrm{M} 4$} & \multicolumn{2}{|c|}{ M5 } & \multicolumn{2}{|c|}{ M6 } & \multicolumn{2}{|c|}{ M7 } \\
\hline & Coef. & $t$-stat & Coef. & $t$-stat & Coef. & $t$-stat & Coef. & $t$-stat & Coef. & $t$-stat & Coef. & $t$-stat & Coef. & $t$-stat \\
\hline & \multicolumn{14}{|c|}{ Panel A: Performance Persistence in Three Months } \\
\hline$\alpha_{(t-12, t-1)}$ & 0.220 & 26.93 & 0.222 & 20.22 & 0.248 & 26.82 & 0.202 & 20.45 & 0.235 & 26.97 & 0.204 & 19.26 & 0.229 & 26.68 \\
\hline Flow $_{(t-12, t-1)}$ & -1.154 & -2.51 & -0.871 & -1.42 & -0.944 & -1.88 & -0.924 & -1.92 & -1.264 & -2.24 & -1.191 & -2.50 & -1.364 & -2.25 \\
\hline Vol x $\alpha_{(t-12, t-1)}$ & & & & & -0.119 & -6.42 & & & & & & & & \\
\hline Up-quiet x $\alpha_{(t-12, t-1)}$ & & & & & & & 0.053 & 3.22 & & & & & & \\
\hline Up-vol x $\alpha_{(t-12, t-1)}$ & & & & & & & & & -0.113 & -4.91 & & & & \\
\hline Down-quiet $x \alpha_{(t-12, t-1)}$ & & & & & & & & & & & 0.038 & 2.42 & & \\
\hline Down-vol x $\alpha_{(t-12, t-1)}$ & & & & & & & & & & & & & -0.090 & -3.46 \\
\hline Vol x LagFlow & & & & & -1.213 & -1.08 & & & & & & & & \\
\hline Up-quiet x LagFlow & & & & & & & 0.265 & 0.30 & & & & & & \\
\hline Up-vol x LagFlow & & & & & & & & & -2.318 & -1.63 & & & & \\
\hline Down-quiet x LagFlow & & & & & & & & & & & 0.477 & 0.55 & & \\
\hline Down-vol x LagFlow & & & & & & & & & & & & & 0.468 & 0.29 \\
\hline Control Variables & Yes & & Yes & & Yes & & Yes & & Yes & & Yes & & Yes & \\
\hline \multirow[t]{2}{*}{ Adjusted $\mathrm{R}^{2}$} & 7.24 & & 7.23 & & 7.36 & & 7.32 & & 7.26 & & 7.26 & & 7.25 & \\
\hline & \multicolumn{14}{|c|}{ Panel B: Performance Persistence in Twelve Months } \\
\hline$\alpha_{(t-12, t-1)}$ & 0.176 & 32.19 & 0.184 & 25.05 & 0.204 & 32.99 & 0.161 & 24.36 & 0.193 & 33.01 & 0.156 & 22.07 & 0.184 & 31.99 \\
\hline Up x $\alpha_{(t-12, t-1)}$ & & & -0.018 & -1.70 & & & & & & & & & & \\
\hline Vol $x \alpha_{(t-12, t-1)}$ & & & & & -0.120 & -9.68 & & & & & & & & \\
\hline Up-quiet x $\alpha_{(t-12, t-1)}$ & & & & & & & 0.044 & 4.00 & & & & & & \\
\hline Up-vol x $\alpha_{(t-12, t-1)}$ & & & & & & & & & -0.125 & -8.09 & & & & \\
\hline Down-quiet $x \alpha_{(t-12, t-1)}$ & & & & & & & & & & & 0.046 & 4.40 & & \\
\hline Down-vol x $\alpha_{(t-12, t-1)}$ & & & & & & & & & & & & & -0.078 & -4.45 \\
\hline Up x LagFlow & & & -0.384 & -0.66 & & & & & & & & & & \\
\hline Vol x LagFlow & & & & & 0.559 & 0.74 & & & & & & & & \\
\hline Up-quiet x LagFlow & & & & & & & -0.538 & -0.90 & & & & & & \\
\hline Up-vol x LagFlow & & & & & & & & & 0.291 & 0.31 & & & & \\
\hline Down-quiet x LagFlow & & & & & & & & & & & 0.173 & 0.30 & & \\
\hline Down-vol x LagFlow & & & & & & & & & & & & & 0.765 & 0.71 \\
\hline Control Variables & Yes & & Yes & & Yes & & Yes & & Yes & & Yes & & Yes & \\
\hline Adjusted $\mathrm{R}^{2}$ & 9.84 & & 9.85 & & 10.10 & & 10.02 & & 9.88 & & 9.89 & & 9.89 & \\
\hline
\end{tabular}


persistence in 3- and 12-month test windows. However, a very different pattern emerges when volatile market dummy replaces up dummy and interacts with fund past performance and lagged flows respectively (M3). While the coefficient estimate of interaction term volatile $\times$ Flow $_{(t-12, t-1)}$ stays insignificant, the coefficient of volatile $\times \alpha_{(t-12, t-1)}$ is significantly negative in both panels. This indicates that the level of fund performance persistence is significantly reduced during volatile markets (volatile dummy=1) compared to quiet markets (volatile dummy=0). Results are consistent with our early conjecture that fund managers usually perform better when market is relatively calm and stable, and with predictable future movements, which will be reflected on the persistence of fund performance in subsequent months. In contrast, managers have very limited capability in generating consistently superior returns during volatile markets as market swings vibrantly without clear directions, giving a hard time for managers to produce persistent performance.

Results from M2 and M3 largely match the observations in the "smart money" test in the previous section. While investors generally possess good ability in selecting successful funds, the flow performance in up markets is not significantly different from that in down markets. On the other hand, flow performance is much better during quiet markets than during volatile markets. Combining the fund performance persistence test with smart money test, we can see that the flow performance is largely driven by the fund performance persistence. Thus, the manager talent and relevant investment strategies could carry forward from the past during quiet markets for one year (Lynch and Musto, 2003; and Berk and Green, 2004). Even though investors can be successful in picking good funds during volatile market periods, the significantly lower performance persistence across the hedge fund industry eliminates the "smart money" effect commonly observed in other market conditions.

To further differentiate the impact of a specific market condition on the fund performance persistence, we follow a similar approach in the previous sections and include one of the following four market dummy variables in the model to interact with lagged fund performance as well as lagged flow respectively: up-quiet, up-volatile, down-quiet, and down-volatile. Models M4 - M7 in Table 7 report test results.

Distinct patterns of performance persistence emerge after the further breakdown of market conditions. In all four models and both testing windows, coefficients of the interaction terms between market dummies and past performance are significant. In particular, during up-quiet and down-quiet markets fund performance persistence is much stronger than other market conditions. In contrast, during upvolatile and down-volatile markets performance persistence is significantly reduced. This observation is consistent with our findings in M2 and M3, where market volatility has a negative impact on performance persistence but there is no difference between up and down markets. Therefore, volatile markets are the 
primary market condition that affects the fund performance and their persistence in a negative way, while quiet markets are where investors see better fund performance and much stronger performance persistence.

Comparing to the smart money tests in the four market breakdowns in the previous table, results from model M4 - M7 offer consistent evidence as well. Due to significantly reduced performance persistence during up-volatile and down-volatile markets, the smart money effect is much weaker or even disappearing in these markets. The observation implies that if hedge fund investors tend to weigh more on past performance to make investment decisions during volatile markets, they are not better off by doing so. In contrast, the smart money effect is much stronger when performance is more persistent during upquiet and down-quiet markets. Thus, the smart money effect largely depends on the performance persistence in a specific market condition.

In sum, we provide evidence to show that market conditions matter for hedge fund performance and fund performance persistence. During volatile markets (both up-volatile and down-volatile markets), past fund performance cannot be used to predict future fund performance and most hedge funds also underperform. This is consistent with Busse's (1999) finding in mutual fund literature. Combining tests in this section and in the previous section, our results imply that down-volatile markets may have a greater negative effect than up-volatile markets. However, upside volatility still hurts fund investors' ability to pick funds, reduces fund managers' ability to provide better performance, and influences fund investors to change their investment strategies. Our overall results demonstrate that both downside and upside volatilities affect investment behaviors. Therefore, upside volatility should not be just neglected. Upside and downside volatilities may be considered separately when developing portfolio theories.

\section{Conclusion}

In this paper we explore how market conditions affect hedge fund performance and fund investors' behavior to shed light on whether investors only respond to downside volatility. Specifically, we focus on how market conditions affect relations between current fund flows and past fund performance, between current fund flows and future fund performance, and between past fund performance and future fund performance.

As previous literature documents, fund investors learn about fund managers' unobserved ability by using fund past performance to make their investment decisions. Therefore, how investors interpret fund performance and how investors relate this learning to future fund performance are essential to the flowperformance relationship and the change of investment behaviors reflect investors' attitude toward some 
unobserved factors. Market risk or uncertainty is one of the most important factors when investors form their portfolio holdings. Recent study suggests that incorporating predictability based on macroeconomic variables can significantly improve hedge fund investor performance. Among all macroeconomic variables, market volatility is one of important factors for evaluating hedge fund performance. Thus, market conditions should have different effects on the fund performance and the level of risk. The varying fund performances and risk will cause investors to show different behaviors.

We classify market conditions as up, down, quiet, volatile, and combinations of up-quiet, up-volatile, down-quiet, and down-volatile markets. Using a sample of 5,254 individual hedge funds from January 1994 to December 2009, we find that fund flows and fund performance in the hedge fund industry vary with market conditions. Market conditions play an important role on the fund performance and fund investors' behavior. We further find that hedge fund investors chase past performance in a highly asymmetric fashion under different market conditions. They invest more in past winners in down-quiet markets but avoid investing in the past winners in the best and worst performance fund groups in the upvolatile markets. We also document the existence of "smart money" effect over both 3- and 12-month periods under all market conditions except volatile markets (both up- and down-volatile markets). We further provide evidence to show that the observed smart money effect is largely associated with fund performance persistence. Fund performance is strongly persistent during quiet markets, leading to a significant smart money effect. In contrast, volatile markets significantly reduce the level of persistence in both 3- and 12-month investment horizons, which contribute to a marginal to disappearing smart money effect.

Our overall results indicate that hedge fund investors have different behaviors between quiet and volatile markets, between each of up- and down-volatile markets and quiet markets, and between up- and down-volatile markets. Although downside volatility may have a stronger negative impact on the fund performance, fund performance persistence and smart money effect, both upside and downside volatilities do provide a drag on investors' ability to pick funds and fund managers' ability to generate better returns. Our results provide evidence to show that market conditions matter to hedge fund investors.

\footnotetext{
Authors Information: Chou: College of Business Administration, Florida International University, Miami, FL 33199; wchou@fiu.edu; (305)348-0533. Ke: Department of Graduate Management Studies, Nathan Weiss Graduate College, Kean University, Union, NJ 07083; dke@kean.edu; (908)737-5967. Xu: School of Business Administration, Gonzaga University, Spokane, WA 99258 and Hanken School of Economics, Helsinki, Finland; xu@jepson.gonzaga.edu; (509) 313-7030. We thank Timo Korkeamaki, Qinghai Wang and seminar participants at 2010 Northeast Business and Economics Association meetings, 2011 Financial Management Association meetings, Florida International University and Hanken School of Economics for their helpful comments and suggestions. All remaining errors are our own.
} 


\section{References}

Agarwal, Vikas and Narayan Y. Naik, (2000). Multi-period performance persistence analysis of hedge funds, Journal of Financial and Quantitative Analysis 35, 327-342.

Agarwal, Vikas, Naveen D. Daniel, and Narayan Y. Naik, (2009). Role of managerial incentives and discretion in hedge fund performance, Journal of Finance 64, 2221-2256.

Ang, Andrew, Joseph Chen, and Yuhang Xing, (2006). Downside Risk, Review of Financial Studies 19, 1191-1239.

Aragon, George O., Bing Liang, and Hyuna Park, (2008). Onshore and offshore hedge funds: Are they twins? Working paper.

Avramova, Doron, Robert Kosowski, Narayan Y. Naik, and Melvyn Teo, (2011). Hedge funds, managerial skill, and macroeconomic variables, Journal of Financial Economics 99, 672-692.

Baba, Naohiko, and Hiromichi Goko, (2009). Hedge fund survival: Non-normal returns, capital outflows, and liquidity, Journal of Financial Research 32, 71-93.

Baquero, Guillermo, and Marno Verbeek, (2009). A portrait of hedge fund investors: Flows, performance and smart money, Working paper, Erasmus University.

Bares, Pierre-Antoine, Rajna Gibson, and Sebastien Gyger, (2003). Performance in the hedge funds industry: An analysis of short and long-term persistence, Journal of Alternative Investments 6, 25-41.

Berk, Jonathan B., and Richard C. Green, (2004). Mutual fund flows and performance in rational markets, Journal of Political Economy 112, 1269-1295.

Busse, Jeffrey A., (1999). Volatility timing in mutual funds: evidence from daily returns, Review of Financial Studies 12, 1009-1041.

Capocci, Daniel, Albert Corhay, and Georges Hübner, (2005). Hedge fund performance and persistence in bull and bear markets, European Journal of Finance 11, 361-392.

Chen, Yong, and Bing Liang, (2007). Do market timing hedge funds time the market?, Journal of Financial and Quantitative Analysis 42, 827-856.

Ding, Bill, Mila Getmansky, Bing Liang, and Russ Wermers, (2009). Share restrictions and investor flows in the hedge fund industry, Working paper.

Docking, Diane Scott, and Paul D. Koch, (2005). Sensitivity of investor reaction to market direction and volatility: Dividend change announcements, Journal of Financial Research 28, 21-40.

Ederington, Louis, Evgenia Golubeva, (2009). Evidence on investor behavior from aggregate stock mutual fund flows, Working paper, University of Oklahoma.

Edwards, Franklin, and Mustafa Onur Caglayan, (2001). Hedge fund and commodity fund investment styles in bull and bear markets, Journal of Portfolio Management 27, 97-108.

Ennis, Richard M., and Michael D. Sebastian, (2003). A critical look at the case for hedge funds, Journal of Portfolio Management 29, 103-112.

Ferson, Wayne E., and Min S. Kim, (2012). The factor structure of mutual fund flows, International Journal of Portfolio Analysis and Management 1, 112-143.

Frazzini, Andrea, and Owen Lamont, (2008). Dumb money: Mutual fund flows and the cross-section of stock returns, Journal of Financial Economics 88, 299-322.

Fung, William, and David A. Hsieh, (1999). A primer on hedge funds, Journal of Empirical Finance 6, 309-331.

Fung, William, and David A. Hsieh, (2000). Performance characteristics of hedge funds and commodity funds: Natural vs. spurious biases, Journal of Financial and Quantitative Analysis 35, 291-307.

Fung, William, and David A Hsieh, (2001). The risk in hedge fund strategies: Theory and evidence from trend followers, Review of Financial Studies 14, 313-341.

Fung, William, and David A Hsieh, (2004). Hedge fund benchmarks: A risk based approach, Financial Analyst Journal, 60, 65-80.

Goetzmann, William N., Jonathan E. Ingersoll, and Stephen A. Ross, (2003). High-water marks and hedge fund management contracts, Journal of Finance 58, 1685-1718. 
Gruber, Martin J., (1996). Another puzzle: The growth in actively managed mutual funds, Journal of Finance 51, 783-810.

Huang, Jennifer, Kelsey D. Wei, and Hong Yan, (2007). Participation costs and the sensitivity of fund flows to past performance, Journal of Finance 62, 1273-1311.

Ivkovi $\square$ Zoran, and Scott Weisbenner, (2009). Individual investor mutual fund flows, Journal of Financial Economics 92, 223-237.

Kaplan, Paul D., and Laurence B. Siegel, (1994a). Portfolio theory is alive and well, Journal of Investing 3, 18-23.

Kaplan, Paul D., and Laurence B. Siegel, (1994b). Portfolio theory is alive and well, Journal of Investing 3, 45-46.

Kelly, Morgan, (1997). Do noise traders influence stock prices?, Journal of Money, Credit, and Banking 29, 351-363.

Keswani, Aneel, and David Stolin, (2008). Dollar-weighted returns to stock investors: A new look at the evidence, Working paper, City University London.

Luo, Dengpan, (2003). Market volatility and mutual fund cash flows, Yale ICF Working paper.

Lynch, Anthony W., and David K. Musto, (2003). How investors interpret past fund returns, Journal of Finance 58, 2033-2058.

Nawrocki, David, (1999). A brief history of downside risk measures, Journal of Investing 3, 9-25.

Ozik, Gideon and Ronnie Sadka, (2009). Smart money or smart about money? Evidence from hedge funds, Working paper, Boston College.

Rom, Brian M., and Kathleen W. Ferguson, (1993). Post-modern portfolio theory comes of age, Journal of Investing 3, 11-17.

Rom, Brian M., and Kathleen W. Ferguson, (1994). Portfolio theory is alive and well: A response, Journal of Investing 3, 24-44.

Roy, Arthur D., (1952). Safety first and the holding of assets, Econometrica 20, 431-449.

Sapp, Travis, and Ashish Tiwari, (2004). Does stock return momentum explain the "smart money" effect?, Journal of Finance 59, 2605-2622.

Savor, Pavel, and Mungo Wilson, (2012). How much do investors care about macroeconomic risk? Evidence from scheduled economic announcements, Journal of Financial and Quantitative Analysis, Forthcoming.

Sirri, Erik R., and Peter Tufano, (1998). Costly search and mutual fund flows, Journal of Finance 53, 1589-1622.

Wang, Ashley, and Lu Zheng, (2008). Aggregate hedge fund flows and asset returns, Working paper.

Zheng, Lu, (1999). Is money smart? A study of mutual fund investors' fund selection ability, Journal of Finance 54, 901-933. 